\title{
1 Quantifying the impact of riverine particulate dissolution in seawater on
}

\section{2 ocean chemistry}

3 Morgan T. Jones ${ }^{1}$, Sigurður R. Gislason ${ }^{2}$, Kevin W. Burton ${ }^{3}$, Christopher R. Pearce ${ }^{4}$, Vasileios

4 Mavromatis $^{5}$, Philip A.E. Pogge von Strandmann ${ }^{6}$ \& Eric H. Oelkers ${ }^{2,6,7}$

$5{ }^{1}$ Centre of Earth Evolution and Dynamics (CEED), University of Oslo, Oslo, Norway

$6 \quad 2$ Institute of Earth Sciences, University of Iceland, Sturlugata 7, Reykjavík, Iceland

$7 \quad{ }^{3}$ Department of Earth Sciences, Durham University, Durham, UK

$8{ }^{4}$ School of Ocean and Earth Science, National Oceanography Centre, Southampton University, $9 \quad$ European Way, Southampton, UK

$10{ }^{5}$ Graz University of Technology, Institute of Applied Geosciences, Rechbauerstraße 12, 8010

11 Graz, Austria

$12{ }^{6}$ Institute of Earth and Planetary Sciences, University College London and Birkbeck College

13 London, Gower Street, London, WC1E 6BT, UK

$14{ }^{7}$ GET-Université de Toulouse-CNRS-IRD-OMP, Toulouse, France

\section{Abstract}

17 The quantification of the sources and sinks of elements to the oceans forms the basis of our

18 understanding of global geochemical cycles and the chemical evolution of the Earth's surface.

19 There is, however, a large imbalance in the current best estimates of the global fluxes to the

20 oceans for many elements. In the case of strontium $(\mathrm{Sr})$, balancing the input from rivers would 
21 require a much greater mantle-derived component than is possible from hydrothermal water flux

22 estimates at mid-ocean ridges. Current estimates of riverine fluxes are based entirely on

23 measurements of dissolved metal concentrations, and neglect the impact of riverine particulate

24 dissolution in seawater. Here we present ${ }^{87} \mathrm{Sr} /{ }^{86} \mathrm{Sr}$ isotope data from an Icelandic estuary, which

25 demonstrate rapid $\mathrm{Sr}$ release from the riverine particulates. We calculate that this $\mathrm{Sr}$ release is

26 1.1-7.5 times greater than the corresponding dissolved riverine flux. If such behaviour is typical

27 of volcanic particulates worldwide, this release could account for 6-45\% of the perceived marine

28 Sr budget imbalance, with continued element release over longer timescales further reducing the

29 deficit. Similar release from particulate material will greatly affect the marine budgets of many

30 other elements, changing our understanding of coastal productivity, and anthropogenic effects

31 such as soil erosion and the damming of rivers.

\section{Introduction}

34 Continental weathering and erosion is the primary control on the transport of material from the continents to the oceans, and a major component of the cycles of many elements on the Earth's

surface. The riverine flux of material from continental weathering is the dominant input of many

elements to the oceans. Ocean chemistry is commonly modelled as a combination of these

$\underline{\text { riverine fluxes, hydrothermal exchange at mid-ocean ridges, and sedimentation coupled to burial }}$

(Riley \& Chester, 1971). Strontium is among the best constrained of the global element cycles

over geologic time due to the facility of measuring its isotopic composition, its significant

41 temporal isotope variations, and its preferential incorporation into marine carbonates. The ratio 
44 the open oceans is currently homogenous at $\sim 0.7092$ (Elderfield, 1986) and $\sim 7.85 \mathrm{mg} / \mathrm{L}$ (Bernat et al., 1972), respectively, as the residence time of Sr greatly exceeds the rate of ocean mixing (Broecker \& Peng, 1982). This value reflects a balance in inputs and outputs between radiogenic

$\underline{\text { Sr derived from the continents and unradiogenic Sr from mantle-derived material. While }}$ spatially homogenous at current levels of precision, seawater ${ }^{87} \mathrm{Sr} /{ }^{86} \mathrm{Sr}$ has varied significantly over geological time (e.g. Veizer et al., 1999). These changes to seawater ${ }^{87} \mathrm{Sr} /{ }^{86} \mathrm{Sr}$ have been used to infer changes in inputs and outputs to the oceans in response to climatic and/or tectonic forcings over geological time (e.g. McArthur et al., 2001); although this is contentious (Palmer \& Edmond, 1992; Oliver et al., 2003). Strontium isotope compositions have also been used as tracers of inputs from different river catchments into intra-continental seas (Andersson et al., $\underline{1991)}$.

$\underline{\text { Seawater }}{ }^{87} \mathrm{Sr} /{ }^{86} \mathrm{Sr}$ has been increasing at a rate of $0.000054 \mathrm{Myr}^{-1}$ in the Neogene and

Pleistocene (Henderson et al., 1994; Hodell et al., 1989). There is a current discrepancy in our scientific understanding of the global Sr cycle, as mass balance calculations indicate that the current input of radiogenic $\mathrm{Sr}$ from the continents, assumed to only be transported in dissolved form to the oceans, cannot be balanced by unradiogenic Sr originating from hydrothermal exchange with oceanic crust to satisfy the observed rate of ${ }^{87} \mathrm{Sr} /{ }^{86} \mathrm{Sr}$ change. The global average dissolved riverine ${ }^{87} \mathrm{Sr} /{ }^{86} \mathrm{Sr}$ input is approximately 0.7136 (Allègre et al., 2010) while $\mathrm{Sr}$ liberated during hydrothermal exchange has a ratio of 0.7029 (Albarède et al., 1981). To balance the input from the world's rivers, the hydrothermal flux would need to be 4-20 times higher than current estimates (Davis et al., 2003; Hodell et al., 1989; Palmer and Edmond, 1989; Vance et al., 2009). 
possibility is a deglacial weathering pulse that has yet to decay, which means that current dissolved riverine measurements would not be representative of the average over a time period greater than glacial/interglacial cycles (Vance et al., 2009). Potential missing fluxes of unradiogenic Sr include groundwater inputs from volcanic terrains (Allègre et al., 2010) and offaxis exchange with oceanic crust (Elderfield and Gieskes, 1982), with the latter considered to be of insufficient magnitude to play a considerable role (Davis et al., 2003).

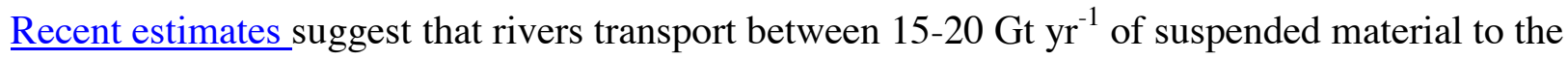
ocean each year (Peucker-Ehrenbrink et al., 2010; Walling, 2006), considerably greater than the dissolved riverine and aeolian fluxes combined (Oelkers et al., 2011;2012). Traditionally it has been assumed that this particulate material undergoes little additional weathering in seawater, because dissolution rates are reduced at low temperatures and because burial is thought to rapidly

79 isolate sediment. Nevertheless, some dissolution of riverine particulate material in the oceans is

80 inevitable, depending upon the saturation states of minerals in seawater, particulate surface area,

81 temperature, and prior weathering history. Experimental determinations of basalt dissolution

82 rates covering the $\mathrm{pH}$ and temperature range of modern seawater suggest that $\sim 0.05 \%$ of basaltic

83 particulate material could dissolve in seawater each day, with potentially profound impacts on

84 seawater chemistry (Gislason et al., 2006). More recently, laboratory experiments have shown

85 that there is substantial release of both soluble elements (such as $\mathrm{Sr}$ ) and insoluble elements

86 (such as Nd) from riverine particulates to seawater over a timescale of days to months (Jones et

87 al., 2012a; 2012b; Pearce et al., 2013). Field evidence also indicates that the dissolution of particles is a significant part of the Nd cycle (Lacan and Jeandel, 2005; Arsouze et al., 2009), including large submarine fans such as from the Ganges/Brahmaputra (Singh et al., 2012). For 

112 Strandmann et al., 2008).

more soluble elements such as $\mathrm{Ca}, \mathrm{Mg}$, and $\mathrm{Sr}$, it is more difficult to observe such release in natural environments. This is due to both their elevated concentrations in seawater, which are several orders of magnitude greater than in the water arriving from estuaries, and the effects of contemporaneous precipitation of secondary minerals and ion-exchange as river-transported particles attempt to equilibrate with their new surroundings (Jones et al., 2012a).

Here we present $\mathrm{Sr}$ elemental and isotope $\left({ }^{87} \mathrm{Sr} /{ }^{86} \mathrm{Sr}\right)$ data for riverine particulates from a basaltic catchment, tracing their pathway from the Hvítá River into the Borgarfjörður Estuary in western Iceland (Fig. 1). This catchment is well suited for the study of seawater-particulate interaction as it has sparse vegetation, poorly developed soils, a stable climate, and a relatively homogenous basaltic geology (c.f. Gislason et al., 1996). High physical erosions rates result in the delivery of readily weathered material with a high surface area. The estuary is $<2 \mathrm{~m}$ deep over the first 5 $\mathrm{km}$ from the river mouth and is consequently tidally-dominated and both vertically and horizontally well mixed. The shallow depth results in a high particulate-water ratio, maximizing both the likelihood of continued particulate weathering, and a detectable chemical response in the estuarine waters. The estuary has a natural narrowing, enhanced by Borgarfjörður Bridge at Borgarnes (Fig. 1); consequently sediment input from outside the catchment is minimal. Previous work on this catchment has demonstrated a distinct difference between the particulate and dissolved compositions of several isotopes and elements including $\mathrm{Sr}$ (Jones et al., 2012a;

Pearce et al., 2010; 2013; Pogge von Strandmann et al., 2008). Crucially, Li isotope data indicates that the river-derived particulates have experienced weathering in this estuary, including both primary phase dissolution and secondary phase precipitation (Pogge von 
114 This study focuses on particle dissolution in a volcanic estuary for a number of reasons.

115 Estimates suggest that humid, young, and mountainous regions account for $40 \%$ of the global

116 dissolved flux and $>60 \%$ of the suspended particulate flux, despite comprising just $14 \%$ of the

117 global drainage area (Milliman and Farnsworth, 2011). Proportionally, volcanic terrains exert a

118 much greater global influence on particulate fluxes to the oceans than expected from their

119 geographical extent, due to the combined effects of high relief, high runoff, the presence of

120 rapidly weathered volcanic rocks, and the absence of sedimentary traps (Milliman and Syvitski,

121 1992). The dissolution rates of primary basaltic minerals are, generally, an order of magnitude

122 or more rapid than those of granitic, metamorphic, or recycled sedimentary minerals (Dupré et

123 al., 2003; Gislason and Oelkers, 2003; Wolf-Boenisch et al., 2004; Gudbrandsson et al., 2012).

124 Moreover, particulate material delivered from volcanic islands typically undergoes little

125 weathering during riverine transport due to rapid transit to the oceans, so they are particularly

126 susceptible to dissolution once they arrive in coastal waters. Hence, elemental release from

127 basaltic particles could potentially account for the imbalances identified in the global cycles of a

128 number of elements. For strontium, the ${ }^{87} \mathrm{Sr} /{ }^{86} \mathrm{Sr}$ isotope composition of basaltic particulates is

129 less radiogenic than seawater, and thus may potentially account for at least part of the apparent

130 shortfall in the marine Sr budget.

\section{2. Methods}

133 2.1 Sampling 
134 Three field excursions were conducted in the Borgarfjörður/Hvitá catchment in 2003, 2008, and

135 2011. Samples were collected in transects along the estuary across the mixing zone of fresh and

136 saline water at high tide (see Fig. 1). The sampling methods from the 2003 field excursion are

137 summarized in Pogge von Strandmann et al. (2008). This sample suite, collected from the

138 Hvítárvellir Bridge to beyond the estuary mouth, represents a range in salinity from riverine

139 water to close to that of pure seawater. Fluid, suspended particles, and some colloid samples

140 were collected. The 2011 transect also started at Hvítárvellir and collected a higher density of

141 samples across the mixing zone, finishing at the bridge at Borgarnes. Surface water samples

142 were collected at a depth of $30 \mathrm{~cm}$, with the exception of sample Bo8b, which was taken using a

143 Niskin sampler at a depth of $2 \mathrm{~m}$ (bottom water at this location). Conductivity and temperature

144 were measured on location. The samples were brought to the laboratory the same day and

145 filtered using a peristaltic pump through a $0.2 \mu \mathrm{m}$ cellulose acetate membrane filter. The

146 samples were then subdivided prior to analysis. The filters were rinsed through with de-ionized

147 water, dried then weighed to estimate the suspended fraction concentration.

149 The 2008 transect collected bedload material that has been the focus of previous investigations

150 (Jones et al., 2012a; Pearce et al., 2013). The sample locations matched that of the locations in

151 2003. In the shallow parts of the river and estuary, samples were collected from exposed

152 sandbanks or using a corer to collect material from the top $20 \mathrm{~cm}$ of the sediment. In deeper

153 water, samples were collected using a weighted bucket dragged behind the boat over a distance

154 of $\sim 10 \mathrm{~m}$. Repeat passes were conducted to collect sufficient material, which were then

155 homogenized prior to splitting into sample containers. All samples were dried at $40{ }^{\circ} \mathrm{C}$

156 immediately after collection but no other processing was performed. 


\subsection{Chemical Analyses}

The filters and particulate material were flushed with $1 \mathrm{~L}$ of de-ionized water and dried at $40{ }^{\circ} \mathrm{C}$ before digestion in $20 \mathrm{ml}$ savillex ${ }^{\circledR}$ containers at $120{ }^{\circ} \mathrm{C}$ for 72 hours using $2 \mathrm{ml} 15 \mathrm{M} \mathrm{HNO}_{3}$. After digestion, samples evaporated to dryness at $75^{\circ} \mathrm{C}$ and re-diluted to $2 \% \mathrm{HNO}_{3}$ prior to elemental analyses. The elemental compositions of these samples after digestion were measured in a Thermo Finnigan ${ }^{\circledR}$ ELEMENT XR at the GET in Toulouse, France. An In Re spike was used for calibration purposes, and the total blank contributions (including blank filters) were negligible for the elements presented in here compared to sample concentrations. Dissolved concentrations of major elements and cations in collected fluid samples were conducted on an ICP-SFMS in ALS laboratories, Sweden. Anion concentrations in these samples were measured using ion chromatography techniques using a Dionex ${ }^{\circledR}$ ICS-2000 in Reykjavík, Iceland.

The ${ }^{87} \mathrm{Sr} /{ }^{86} \mathrm{Sr}$ ratios of each sample were measured using a VG Sector 54 thermal ionization mass spectrometer (TIMS). Liquid and pre-digested solid samples were evaporated, taken up in 3M

$172 \mathrm{HNO}_{3}$ and run through $\mathrm{Sr}-\mathrm{spec}$ columns. The purified $\mathrm{Sr}$ was then loaded onto outgassed Ta

173 filaments. The samples were run at ${ }^{88} \mathrm{Sr}$ beam potentials of $2 \mathrm{~V}$ and 100 ratios were collected

174 using a multi-dynamic peak jumping routine. Resulting ${ }^{87} \mathrm{Sr} /{ }^{86} \mathrm{Sr}$ ratios were normalized to an

$175{ }^{86} \mathrm{Sr} /{ }^{88} \mathrm{Sr}$ ratio of 0.1194 . Six analyses of the NBS 987 standard yielded an average ${ }^{87} \mathrm{Sr} /{ }^{86} \mathrm{Sr}$ of

$1760.710243 \pm 0.000010(2 \mathrm{SD})$. Individual errors did not exceed $\pm 0.000012{ }^{87} \mathrm{Sr} /{ }^{86} \mathrm{Sr}$. Total

177 blanks for Sr were found to be negligible compared to the Sr amounts from the samples.

\section{$\underline{2.3 \text { Mixing Calculations }}$}


185

\section{$199 \quad$ 3. $\quad$ Results}

This study focusses on the Sr isotope compositional evolution in Borgarfjörður estuary as river water mixes with seawater. $\mathrm{The}^{87} \mathrm{Sr} /{ }^{86} \mathrm{Sr}$ ratio of the estuary water in this system, if it was controlled by the mechanical mixing of two sources (the dissolved Sr present in the river and in seawater) would be given by:

$\left(\frac{{ }^{87} \mathrm{Sr}}{{ }^{86 \mathrm{Sr}}}\right)_{2 \text { comp }}=\left(F_{\text {river }} \times\left(\frac{{ }^{87} \mathrm{Sr}}{{ }^{86 \mathrm{Sr}}}\right)_{\text {river }}\right)+\left(\left(1-F_{\text {river }}\right) \times\left(\frac{{ }^{87} \mathrm{Sr}}{{ }^{86 \mathrm{Sr}}}\right)_{x}\right)$

where $\left(\frac{{ }^{87} \mathrm{Sr}}{{ }^{86} \mathrm{Sr}}\right)_{2 \text { comp }}$ refers to the isotopic ratio expected in the samples based on 2-component $\underline{\text { mechanical mixing, }\left(\frac{{ }^{87} \mathrm{Sr}}{{ }^{86} \mathrm{Sr}}\right)_{\text {river }} \text { refers to the isotopic ratio of the Hvítá river end-member }}$ $\underline{(0.70459), \text { and }}\left(\frac{{ }^{87} \mathrm{Sr}}{{ }^{86} \mathrm{Sr}}\right)_{x} \underline{\text { refers to the isotopic value of non-riverine derived } \mathrm{Sr} \text {, which in this case }}$ is equal to the isotopic ratio of seawater $\left({ }^{87} \mathrm{Sr}^{86} \mathrm{Sr}_{s w}=0.709198\right) . \boldsymbol{f}_{\text {river }}$ refers to the fraction of dissolved riverine-derived $\mathrm{Sr}$ in the water, calculated from dissolved $\mathrm{Cl}$ concentrations:

$\boldsymbol{f}_{\text {river }}=\left(\frac{[C l]_{\text {est }}-[C l]_{s w}}{[C l]_{\text {river }}-[C l]_{s w}}\right) \times\left(\frac{[C l]_{\text {river }}}{\left[C l l_{e s t}\right.}\right)$ where the suffixes est, sw and river refer to the estuarine sample, the river end-member, and the seawater end-member, respectively. The first part of the equation calculates the relative masses of the two water bodies, which is effectively $\sim 1$ in the low salinity mixing zone. The degree to which the Sr composition of Borgarfjördur estuarywater is consistent with the mechanical mixing of the dissolve $\mathrm{Sr}$ in the river and the seawater will be assessed in detail below. 
The measured element concentrations and ${ }^{87} \mathrm{Sr} /{ }^{86} \mathrm{Sr}$ ratios of all collected fluids are shown in Table 1 . The variation of estuary water $\mathrm{Sr}$ concentrations are plotted against the corresponding Cl concentrations in Fig. 2. The solid line in this figure illustrates the mechanical mixing line between river and sea water. Both sample sets plot close to the mechanical mixing line, with a slight suggestion of a net removal of $\mathrm{Sr}$ in the low-salinity part of the mixing zone. Note that there is a consistent difference in both elemental concentrations and ${ }^{87} \mathrm{Sr} /{ }^{86} \mathrm{Sr}$ ratio between the 2003 and 2011 samples at Hvítárvellir, which may indicate a greater input of sea-spray derived Sr into the catchment in the 2003 samples.

The measured estuary fluid ${ }^{87} \mathrm{Sr} /{ }^{86} \mathrm{Sr}$ ratios are plotted as grey circles a function of the corresponding aqueous $\mathrm{Cl}$ concentrations in Fig. 3. The solid curve in this figure illustrates the $\underline{\text { Sr isotope compositions consistent with the mechanical mixing between river and estuary water }}$ as calculated using Eqns. 1 and 2. Although the estuary water total Sr concentrations plotted in Fig. 2 suggest close to conservative mixing of river and sea water, their ${ }^{87} \mathrm{Sr} /{ }^{86} \mathrm{Sr}$ ratios deviate markedly from simple two-component mixing (Fig. $\underline{3}$ ). These same ${ }^{87} \mathrm{Sr} /{ }^{86} \mathrm{Sr}$ ratios are plotted as a function of the fraction of river water component in the estuary water in Fig. 4. The distribution of the symbols shows a clear deviation from the two component mixing line. The difference between the observed and calculated two-component mixing ${ }^{87} \mathrm{Sr} /{ }^{86} \mathrm{Sr}$ values are consistently more than an order of magnitude greater than the measurement error of \pm 0.000012 , indicating that this is a robust and sizeable deviation from simple mixing. The difference between the measured estuary water ${ }^{87} \mathrm{Sr} /{ }^{86} \mathrm{Sr}$ ratios and those estimated from a two component mixing model are shown as a function of the corresponding $\mathrm{Cl}$ concentrations in Fig. 5. This ${ }^{87} \mathrm{Sr} /{ }^{86} \mathrm{Sr}$ deviation is evident from a Cl concentration of approximately $50 \mathrm{mg} / \mathrm{L}$. At its 
223 maximum, the dissolved ${ }^{87} \mathrm{Sr} /{ }^{86} \mathrm{Sr}$ ratio in the mixing zone is $690 \underline{( \pm 135)}$ and $3460 \underline{( \pm 920)} \mathrm{ppm}$

$224\left(10^{-6}\right)$ lower than that predicted by conservative mixing in 2011 and 2003, respectively. Note the

225 considerably larger errors for the 2003 dataset are due to the inherent uncertainties of using a

226 riverine end-member from a different spot-sample set. Experimentally derived dissolution rates

227 of basaltic particulates from Icelandic catchments in seawater have shown both bedload and

228 suspended sediment from Icelandic river catchments react to change the seawater ${ }^{87} \mathrm{Sr} /{ }^{86} \mathrm{Sr}$

229 without a contemporaneous change in $\mathrm{Sr}$ concentrations over a period of days to months (Jones

230 et al., 2012a; 2012b). These laboratory dissolution rates after 1 to 4 days are shown as an

231 expected deviation from pure mechanical mixing in Fig. 5. Both the 2003 and 2011 sample sets

232 approach the calculated offset after just one day, the minimum residence time of suspended

233 particles in the estuary.

The concentration and $\mathrm{Sr}$ content of the suspended particulate load are summarized in Table 1.

The suspended load concentration is relatively constant and ranges from $492-650 \mathrm{mg} / \mathrm{L}$ in the

estuary. The Sr concentrations of this suspended particulate load also remain close to constant in

the mixing zone and ranges from $146-228 \mathrm{mg} / \mathrm{kg}$. The ${ }^{87} \mathrm{Sr} /{ }^{86} \mathrm{Sr}$ ratios of these suspended

particles are illustrated as a function of the $\mathrm{Cl}$ concentration of their adjacent fluid in Fig. 3. In

contrast with the total concentration of the particles and their total $\mathrm{Sr}$ concentration, the ${ }^{87} \mathrm{Sr} /{ }^{86} \mathrm{Sr}$

ratios of the suspended particles show a dramatic shift towards seawater values in the estuary.

The chemical composition of the bedload samples collected during 2008 are listed in Table 2.

The ${ }^{87} \mathrm{Sr} /{ }^{86} \mathrm{Sr}$ ratios of these bedload samples are illustrated as a function of the $\mathrm{Cl}$ concentration

of their adjacent fluid in Fig. 3. The bedload sample ${ }^{87} \mathrm{Sr} /{ }^{86} \mathrm{Sr}$ ratios follow a similar trend as the 
suspended particles but exhibit less of a seawater $\mathrm{Sr}$ isotope signal than the corresponding suspended particulate material. The Sr concentrations in the bedload increase away from the river mouth due to the presence of carbonate minerals (Jones et al., 2012a). That study concluded from mass balance equations that up to $14.9 \%$ of the original basaltic $\mathrm{Sr}$ has been removed from the non-carbonate bedload.

\section{Discussion}

\subsection{Estimation of the Sr fraction inputted to the estuary waters from particulate material}

The degree to which Sr originating from particulate phases influences the estuarine water

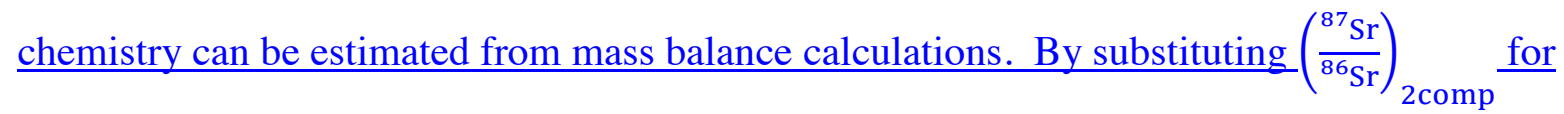

$\left(\frac{{ }^{87} \mathrm{Sr}}{{ }^{86 \mathrm{Sr}}}\right)_{\text {sample }}$ into Eqn. (1) and rearranging, one obtains:

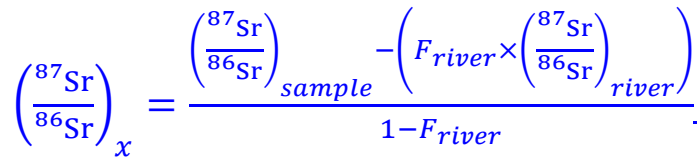

The difference between $\left(\frac{{ }^{87} \mathrm{Sr}}{{ }^{86} \mathrm{Sr}}\right)_{x}$ and $\left(\frac{{ }^{87} \mathrm{Sr}}{{ }^{86} \mathrm{Sr}}\right)_{s w}$ originates from a Sr source other than the conservative mixing of river and sea water. It is assumed in this study that this difference occurs from the conservative transfer of $\mathrm{Sr}$ from particulates to the fluid phase, and from the fluid to the particulates. Taking account of this assumption, the fraction of the $\mathrm{Sr}$ present in the estuarine water samples originating from particulate weathering $\left(f_{\text {part }}\right)$ can then be obtained from: 
$\left.265 \quad \boldsymbol{f}_{\text {part }}=\frac{\left(\frac{{ }^{87} \mathrm{Sr}}{{ }^{86} \mathrm{Sr}}\right)-\left(\frac{{ }^{87} \mathrm{Sr}}{{ }^{86} \mathrm{Sr}}\right)_{s w}}{\left(\frac{{ }^{87} \mathrm{Sr}}{{ }^{86} \mathrm{Sr}}\right)_{\text {part }}-\left({ }^{87} \mathrm{Sr}\right.}\right)_{s w}$

where the subscript part designates the value of the particulate material, where the measured

$\left(\frac{{ }^{87} \mathrm{Sr}}{{ }^{86} \mathrm{Sr}}\right)_{\text {part }}=0.703294$. The total amount of Sr released from the particles to the fluid is attained

by multiplying the dissolved $\mathrm{Sr}$ in the water by $\boldsymbol{f}_{\text {part }}$; the results of this calculation are provided in

Supplementary Table 1. Note that the quantification of the particulate material release is

severely hampered by the difference in element concentrations between the fresh and saline

water. Consequently, the calculations either induce high errors at very low salinity levels, or are

$\underline{\text { swamped by the seawater signature in high salinity areas. As such, } \boldsymbol{f}_{\text {part }} \text { values are only reported }}$

$\underline{\text { over the } 100<\mathrm{Sr}<1000 \mu \mathrm{g} / \mathrm{L} \text { concentration range. In this mid-mixing zone, measured }{ }^{87} \mathrm{Sr} /{ }^{86} \mathrm{Sr}}$

compositions require that an average $3.98( \pm 2.7) \mu \mathrm{g} / \mathrm{L}$ of $\mathrm{Sr}$ be transferred from the particulates

into the water. As these samples were collected at high tide, this Sr must have been liberated

from the particulates to the seawater in a matter of minutes to hours.

Similarly, mass balance calculations can be used to validate if the compositions of the suspended

particle samples collected in 2011 are consistent with these being the source of the unradiogenic

$\underline{\text { Sr required to balance the Sr composition of the estuary water. Taking account of mass balance }}$

constraints, the fraction of Sr in the particles originating from seawater $\left(f_{s w}\right)$ can be calculated from: 
where the subscripts sample, basalt, and $s w$ refer to values for suspended particles in the estuary, the basaltic Hvítá river end member, and the isotopic composition of seawater, respectively. As the Sr concentrations in the particles are close to constant, the total mass of Sr transferred to the estuarine waters from the particles $\left(\mathrm{m}_{\mathrm{Sr} \text { released }}\right)$ is approximately:

$\mathrm{m}_{\text {Sr released }}=\boldsymbol{f}_{s w} \times \mathrm{m}_{\text {Sr particles }}$

where $\mathrm{m}_{\text {Sr particles }}$ refers to the mass of Sr present in the particles. This assumes that the provenance of the suspended material in the mixing zone is dominantly of terrestrial origin.

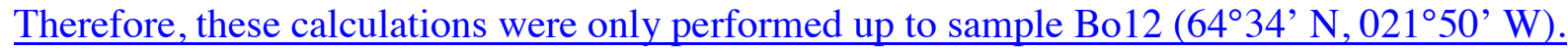
The depth at Bo12 is $<2 \mathrm{~m}$ and well within the confines of the estuary, which supports the assumption that the overwhelming majority of suspended particulates in this part of the estuary originate from the Hvítá catchment. This is also the final sample site used for estimating $\boldsymbol{f}_{\text {part }}$ above. The seawater component $\left(\boldsymbol{f}_{s w}\right)$ is expressed as a percentage in Supplementary Table 1 and Fig. 6 to provide a comparison with the estimates generated from the estuarine water compositions.

The ${ }^{87} \mathrm{Sr} /{ }^{86} \mathrm{Sr}$ composition of the suspended load samples from 2011 indicates that $<0.1 \%$ of the Sr in the suspended particles originated from seawater in the Hvítá River, but $86 \%$ of the $\mathrm{Sr}$ in suspended particles has a seawater signature at the Borgarfjörður Bridge. This observation indicates that the transformation of the Sr isotopic compositions of the particles begins at very low salinity levels (Fig. 6). Note that part of the isotopic evolution could be an artefact due to contamination from residual salts on the filter, even after rinsing with deionized water. However, the dramatic Sr isotopic evolution observed in the particulate material collected from 

327 reflect the larger residence time of the particulates in the mixing zone. resuspension through tidal action. change in the suspended material demonstrates that the particulate fraction is the major

the low salinity mixing zone, confirms that this effect is not an artefact of contamination. Logically, one would expect that if there was any deviation from the dissolved mechanical mixing line in the fjord, the particles would be more unradiogenic than their host water due to

The change in ${ }^{87} \mathrm{Sr} /{ }^{86} \mathrm{Sr}$ in the suspended particles while maintaining a near constant total $\mathrm{Sr}$ concentration indicates the two way transfer of material from and into the particles. In total, the calculations presented above, based on the composition of the suspended particles collected in $2011_{2}$ indicate that $9-27 \mu \mathrm{g} / \mathrm{L}$ of $\mathrm{Sr}$ is transferred from the particles to the estuarine waters in the mixing zone. This mass is 2.5-7.5 times greater than the input to seawater by dissolved riverine transport and approximately $10-30 \%$ of the total particulate $\mathrm{Sr}$ concentrations. Nevertheless, $\underline{\text { these values are substantially greater than the corresponding estimates based on the analysis of }}$ the concentrations of the estuary waters. The most likely reasons for this are a longer residence $\underline{\text { time of particulates in the mixing zone compared to river water, and the formation of, and }}$ exchange with Sr-bearing phases within the estuary. Nevertheless, the dramatic compositional contributor of Sr to estuarine waters through dissolution and/or exchange of Sr. The larger estimated $\mathrm{Sr}$ release deduced from the suspended material compositions compared to that indicated by the estuarine water compositions (1.1 times greater than the dissolved flux) may

329 The question remains as to whether the Sr released from particulates is sourced by the

330 dissolution of or exchange from primary igneous minerals, secondary weathering phases, or even 
331 colloids. Data from Hvítárvellir suggests that the $\mathrm{Sr}$ concentration of riverine colloids is far too

332 low $(0.06 \mathrm{ng} / \mathrm{g})$ for their flocculation to impact seawater chemistry. However, the $\mathrm{Sr}$

333 concentration in Fe-Mn oxyhydroxides (1.8-2.4 $\mu \mathrm{g} / \mathrm{g})$ suggests that these phases may be a

334 significant source, consistent with the observed effects on ${ }^{234} \mathrm{U} /{ }^{238} \mathrm{U}$ activity ratios (Pogge von

335 Strandmann et al., 2008). Therefore, at least part of the two-way transfer of Sr between the

336 particulate and fluid phases could stem from adsorption-desorption processes, as shown by Li

337 isotopes (Pogge von Strandmann et al., 2008). Further insight into the mechanism responsible

338 for the reincorporation into the solid phase can be gained from Fig. 7, which illustrates the $\mathrm{Sr} / \mathrm{Al}$

339 ratio against the $\mathrm{Ca} / \mathrm{Al}$ ratio for the bedload particulate material. These concentration ratios plot

340 as a near linear function of one another with a slope of 0.028 . This dependence suggests that the

341 re-incorporation of $\mathrm{Sr}$ into the solids is due to its co-precipitation with $\mathrm{Ca}$ as the particulate

342 material interacted with seawater in the estuary. It seems likely that this precipitating phase is

343 calcite, given its high concentrations in these sediments (Pearce et al., 2013). The fact that this

344 linear correlation is offset from the origin by $0.6 \mathrm{Ca} / \mathrm{Al}$ implies that a substantial fraction of $\mathrm{Sr}$ in

345 the particulate material is hosted by non-carbonate phases (such as silicates).

\section{$\underline{4.2 \text { Global Implications }}$}

348 These findings have far-reaching implications for the global element cycles. On a catchment

349 scale, the Hvítá River has a mean discharge of $89 \mathrm{~m}^{3} \mathrm{~s}^{-1}$, with an annual particulate suspended

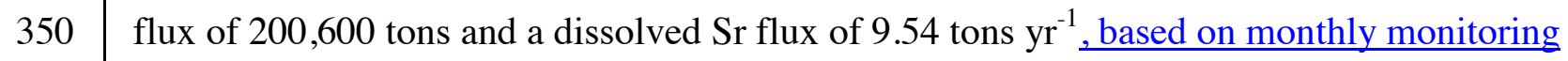

351 (Eiriksdottir et al., 2011). The results described here indicate that a further 10.4-71.5 tons $\mathrm{yr}^{-1}$ of

352 Sr will be transferred to the estuarine waters from particulates, assuming a linear covariance

353 between the dissolved and suspended flux throughout the year. In this case, the overall ${ }^{87} \mathrm{Sr} /{ }^{86} \mathrm{Sr}$ 
354 composition delivered to the ocean (both riverine dissolved and that from particulate dissolution)

355 is calculated to be between 0.70345 and 0.70391 , rather than the value of 0.70459 of the riverine

356 dissolved signal alone. If this behaviour is typical for volcanic particulates worldwide, then

357 consideration of the geographic extent of volcanic islands and basaltic terrains (as defined by

358 Allègre et al., 2010 and Dessert et al., 2003) suggests from 42 and $291 \times 10^{9} \mathrm{~g} \mathrm{yr}^{-1}$ of Sr could be

359 released in this way. This release could account for between 6 and $45 \%$ of the current perceived

360 imbalance in the marine Sr budget, which is of comparable magnitude to the contribution from

361 hydrothermal exchange (Davis et al., 2003). Estimations of annual fluxes based on summer spot

362 sampling from this catchment gave the dissolved Sr flux from Hvítá as 37 tons $\mathrm{yr}^{-1}$ (Pogge von

363 Strandmann et al., 2008), underlining the sensitivity of these calculations to the conditions at the

364 time of sampling. Crucially, these calculations only take into account the initial release of Sr in

365 the estuary; whereas reworking of the sediments is likely to continue to react over much longer

366 periods (e.g. Aller 1998), as exhibited by the experimental evidence (Jones et al., 2012a; 2012b;

367 Pearce et al., 2013).

369 While these results are conclusive field evidence of 'proof of process', there is some degree of

370 uncertainty associated with the magnitude of this flux, especially when scaled up to a global

371 process. Therefore, these may not necessarily be a fair reflection on the annual fluxes. There are

372 considerable climatic differences between Iceland and other basaltic provinces and outcrops

373 worldwide, which would result in varying degrees of weathering, soil formation, and denudation.

374 Moreover, Iceland hosts several sub-glacial volcanoes that lead to the formation of significant

375 amounts of easily-weathered hyaloclastite (hydrated tuff-like breccia that is rich in volcanic

376 glass, formed through water-lava interaction). Each of these variables would affect the partition 
377 of Sr between the solid and fluid phases. Moreover, the relative contributions of mineral and

378 oxyhydroxide dissolution need to be more accurately quantified before firm flux estimates can be

379 made. Despite these uncertainties, the magnitude of these deviations in ${ }^{87} \mathrm{Sr} /{ }^{86} \mathrm{Sr}$ from a two

380 component mixing curve is clear evidence that the reactions of particulate material upon arrival

381 in coastal waters are a major contributor to the global cycle of $\mathrm{Sr}$.

\section{5. Conclusions}

384 These results represent the first direct evidence that the weathering of riverine particulate

385 material upon arrival in coastal areas makes a significant contribution to the overall Sr chemistry of seawater over geological timescales. This is significant as marine ${ }^{87} \mathrm{Sr} /{ }^{86} \mathrm{Sr}$ values are a

387 default tool for estimating weathering rates over geological time. Moreover, this evidence

388 demonstrates that we may have underestimated the elemental mass of material being transferred

389 from the continents to the oceans. The feedback between climate and weathering is commonly

390 quantified based upon the mass of the alkali earth metals $\mathrm{Ca}$ and $\mathrm{Mg}$ transferred from the

391 continents to the oceans during weathering, which consume atmospheric $\mathrm{CO}_{2}$ both during

392 chemical weathering and the precipitation of carbonates (e.g. Walker, et al., 1981; Berner et al.,

393 1983; Berner, 2004; Berner and Kothavala, 2001; Wallmann, 2001). If Ca and Mg behave in a

394 similar fashion to $\mathrm{Sr}$, then the feedback between climate and weathering is stronger than

395 previously presumed (Eiriksdottir et al., 2013).

397 As the overwhelming mass of sparingly soluble bio-limiting nutrients such as $\mathrm{Fe}$ and $\mathrm{P}$ are

398 brought to the oceans in particulate form, the dissolution of these particulates in seawater could

399 provide a new stronger link between continental weathering and marine primary productivity. 
Experimental and field studies demonstrate that elements such as Nd are similarly released from particulate material into seawater, despite its preference for the solid phase (e.g. Pearce et al., 2013; Singh et al., 2012). Such observations suggest that particulate weathering in estuaries is a major contributor of these and other elements to seawater, lending weight to the "Boundary

404 Exchange" hypothesis where sediment-seawater reactions in shelf environments are a significant 405 source of the dissolved constituents in seawater (Jeandel, 1993; Lacan and Jeandel, 2005; 406 Jeandel et al., 2007; 2011; Siddall et al., 2008; Arsouze et al., 2009; Horikawa et al., 2011; Cater 407 et al., 2012; Wilson et al., 2012). These findings also add weight to previous studies, where 408 current land-to-ocean fluxes are proposed to be out of equilibrium following a recent 409 deglaciation (Vance et al., 2009). As glacial retreats expose substantial quantities of finely 410 ground material, the reactions of the particles in seawater provide an efficient mechanism for the 411 enhanced global weathering rates in addition to changes in the dissolved transport.

412 Anthropogenic changes to sediment fluxes through soil erosion and the damming of rivers are 413 likely to affect elemental and nutrient fluxes to coastal waters to a much greater extent than has 414 been previously considered, which may have deleterious consequences for coastal ecosystems.

\section{Acknowledgments}

417 We are indebted to Jérôme Gaillardet and another anonymous reviewer for thorough and 418 constructive reviews. We extend our thanks to Björgunarsveitin Brá, Emily Jones, Eydis 419 Eiriksdóttir, Haraldur Rafn Ingvason, Olivia Jones, Pierre Brunet, Rósa Ólafsdóttir, and Snorri 420 Guðbrandsson and for sampling and technical assistance. M.T.J. was supported by a Marie Curie 421 Intra-European Fellowship (PIEF-GA-2009-254495). 


\section{References}

424 Albarède, F., Michard, A., Minster, J., Michard, G., 1981. ${ }^{87} \mathrm{Sr} /{ }^{86} \mathrm{Sr}$ ratios in hydrothermal 425 waters and deposits from the East Pacific Rise at $21^{\circ}$ N. Earth Planet. Sci. Lett. 55, 229426236.

427 Allègre, C., Louvat, P., Gaillardet, J., Meynadier, L., Rad, S., Capmas, F., 2010. The 428 fundamental role of island arc weathering in the oceanic Sr isotope budget. Earth Planet. 429 Sci. Lett. 292, 51-56.

430 Aller, R. 1998. Mobile deltaic and continental shelf muds as suboxic, fluidized bed reactors. $431 \quad$ Mar. Chem. 61, 143-155.

432 Andersson, P.S., Wasserburg, G.J., Ingri, J., 1992. The sources and transport of Sr and Nd 433 isotopes in the Baltic Sea. Earth Planet. Sci. Lett. 113, 459-472.

434 Arsouze, T., Dutay, J.-C., Lacan, F., Jeandel, C., 2009. Reconstructing the Nd oceanic cycle 435 using a coupled dynamical-biogeochemical model. Biogeosciences 6, 1-18.

436 Bernat, M., Church, T., Allègre, C.J., 1972. Barium and strontium concentrations in Pacific and 437 Mediterranean seawater profiles by direct isotope dilution spectrometry. Earth Planet. $438 \quad$ Sci. Lett. $16,75-80$.

439 Berner, R.A., 2004. The Phanerozoic Carbon Cycle. Oxford University Press, Oxford.

440 Berner, R.A., Kothavala, Z., 2001. GEOCARB III. A revised model of atmospheric $\mathrm{CO}_{2}$ over 441 Phanerozoic time. Am. J. Sci. 301, 182-204. 
442 Berner, R.A., Lasaga, A.C., Garrels, R.M., 1983. The carbonate-silicate geochemical cycle and 443 its effect on atmospheric carbon dioxide over the past 100 million years. Am. J. Sci. 283, $444 \quad 641-683$.

445 Broecker, W.S., Peng, T.H., 1982. Tracers in the Sea (Eldigio Press, Lamont Doherty Geological 446 Observatory).

447 Cater, P., Vance, D., Hillenbrand, C.D., Smith, J.A., Shoosmith, D.R., 2012. The neodymium 448 isotopic composition of water masses in the eastern Pacific sector of the Southern Ocean. 449 Geochim. Cosmochim. Acta, 79, 41-59.

450 Davis, A., Bickle, M., Teagle, D., 2003. Imbalance in the oceanic strontium budget, Earth $451 \quad$ Planet. Sci. Lett. 112, 173-187.

452 Dessert, C., Dupré, B., Gaillardet, J., François, L.M., Allègre, C.J., 2003. Basalt weathering laws 453 and the impact of basalt weathering on the global carbon cycle, Chem. Geol. 202, 257454273.

455 Dupré, B., Dessert, C., Oliva, P., Goddéris, Y., Viers, J., Francois, L., Millot, R., Gaillardet, J., 456 2003. Rivers, chemical weathering and Earth's climate. C.R. Geosci. 335, 1141-1160.

457 Eiriksdottir, E.S., Gislason, S.R., Snorrason, Á., Harðardóttir, J., Porláksdóttir, S.B., 458 Eypórsdóttir, K.G., 2011. Efnasamsetning, Rennsli og Aurburður Straumvatna á 459 Versturlandi V. Gagnagrunnur Jarðvísindastofnunar og Veðurstofunnar (Science Institute 460 Report 04, Haskóli Íslands).

461 Eiriksdottir, E.S., Gislason, S.R., Oelkers, E.H., 2013. Does temperature or runoff control the 462 feedback between chemical denudation and climate? Insights from NE Iceland. 463 Geochim. Cosmochim. Acta 107, 65-81. 
464 Elderfield, H. \& Gieskes, J.M., 1982. Sr isotopes in interstitial waters of marine sediments from Deep Sea Drilling Project cores, Nature 300, 493-497.

Elderfield, H., 1986. Strontium isotope stratigraphy. Palaeogeogr. Palaeoclimatol. Palaeoecol. $57,71-90$

468 Gislason, S.R., Arnórsson, S., Ármannsson, H., 1996. Chemical weathering of basalt in SW Iceland: Effects of runoff, age of rocks and vegetative/glacial cover. Am. J. Sci. 296, 837-

Gislason, S.R., Oelkers, E.H., 2003. The mechanism, rates and consequences of basaltic glass dissolution: II. An experimental study of the dissolution rates of basaltic glass as a function of $\mathrm{pH}$ and temperature. Geochim. Cosmochim. Acta 67, 3817-3832.

474 Gislason, S.R., Oelkers, E.H., Snorrason, A., 2006. Role of river-suspended material in the 475 global carbon cycle. Geology 34, 49-52.

476 Gudbrandsson, S., Wolff-Boenisch, D., Gislason, S.R., Oelkers, E.H., 2011. An experimental study of crystalline basalt dissolution from $2 \leq \mathrm{pH} \leq 11$ and temperatures from 5 to 75

Henderson, G.M., Martel, D.J., O’Nions, R.K., Shackleton, N.J., 1994. Evolution of seawater ${ }^{\circ} \mathrm{C}$. Geochim. Cosmochim. Acta, 75, 5496-5509.

482 Hodell, D., Mueller, P., McKenzie, J., Mead, G., 1989. Strontium isotope stratigraphy and geochemistry of the late Neogene ocean, Earth Planet. Sci. Lett. 92, 165-178.

484 Horikawa, K., Martin, E.E., Asahara, Y., Sagawa, T., 2011. Limits on conservative behaviour of 485 $\mathrm{Nd}$ isotopes in seawater assessed from analysis of fish teeth from Pacific cores. Earth 
Planet. Sci. Lett., 310, 119-130.

487 Jeandel, C. 1993. Concentration and isotopic composition of $\mathrm{Nd}$ in the South Atlantic Ocean. $488 \quad$ Earth Planet. Sci. Lett. 117, 581-591.

489 Jeandel, C., Arsouze, T., , F., Techine, P. and Dutay, J.C. 2007. Isotopic Nd compositions and 490 concentrations of the lithogenic inputs into the ocean: A compilation, with an emphasis on 491 the margins. Chem. Geol. 239, 156-164.

492 Jeandel, C., Peucker-Ehrenbrink, B., Jones, M.T., Pearce, C.R., Oelkers, E.H., Godderis, Y., 493 Lacan, F., Aumont, O. and Arsouze, T. 2011. Ocean Margins: The missing term for $494 \quad$ oceanic element budgets? EOS 92, 217-219.

495 Jones, M.T., Pearce, C.R., Oelkers, E.H., 2012a. An experimental study of the interaction of 496 basaltic riverine particulate material and seawater. Geochim. Cosmochim. Acta 77, 108$497 \quad 120$.

498 Jones, M.T.,Pearce,C.R.,Jeandel,C.,Gislason,S.R.,Eiriksdottir,E.S.,Mavromatis,V., Oelkers,

499 E.H., 2012b. Riverine particulate material dissolution as a significant flux of strontium to 500 the oceans. Earth Planet. Sci. Lett. 355-356, 51-59.

501 Lacan, F., Jeandel, C., 2005. Neodymium isotopes as a new tool for quantifying exchange fluxes 502 at the continent-ocean interface. Earth Planet. Sci. Lett. 232, 245-257.

503 McArthur, J.M., Howarth, R.J., Bailey, T.R., 2001. Strontium Isotope Stratigraphy: LOWESS

$504 \quad$ Version 3: Best Fit to the Marine Sr-Isotope Curve for 0-509 Ma and Accompanying 505 Look-up Table for Deriving Numerical Age, J. Geol. 109, 155-170.

506 Milliman, J.D., Farnsworth, K.L., 2011. River Discharge to the Coastal Ocean: A Global $507 \quad$ Synthesis. Cambridge University Press. 
Milliman, J.D., Syvitski, J., 1992. Geomorphic/tectonic control of sediment discharge to the ocean: the importance of small mountainous rivers. J. Geol. 100, 525-544.

510 Oelkers, E.H., Gislason, S.R., Eiriksdottir, E.S., Jones, M.T., Pearce, C.R. and Jeandel, C. 2011. The role of riverine particulate material on the global cycles of the elements. Appl. Geochem. 26, S365-S369.

513 Oelkers, E.H., Gislason, S.R., Eiriksdottir, E.S., Jones, M.T., Pearce, C.R., Jeandel, C.,

514 2012. Riverine particulate material dissolution in seawater and its implications for the global cycles of the elements. C.R. Geosci. 344, 646-651.

516 Oliver, L., Harris, N., Bickle, M., Chapman, H., Dise, N., Horstwood, M., 2003. Silicate weathering rates decoupled from the ${ }^{87} \mathrm{Sr} /{ }^{86} \mathrm{Sr}$ ratio of the dissolved load during Himalayan erosion. Chem. Geol., 201 (1-2), 119-139.

Palmer, M., Edmond, J., 1989. The strontium isotope budget of the modern ocean, Earth Planet.

Palmer, M. R., Edmond, J. M., 1992, Controls over the strontium isotope composition of river Sci. Lett. 92, 11-26. water: Geochim. Cosmochim. Acta, 56, 2099-2111. Molybdenum isotope behaviour accompanying weathering and riverine transport in a basaltic terrain. Earth Planet. Sci. Lett. 295, 104-114.

Pearce, C.R., Jones, M.T., Oelkers, E.H., Pradoux, C., Jeandel, C., 2013. The effect of particulate dissolution on the neodymium (Nd) isotope and Rare Earth Element (REE) composition of seawater. Earth Planet. Sci. Lett. 369, 138-147 
529 Peucker-Ehrenbrink, B., Miller, M.W., Arsouze, T., Jeandel, C., 2010. Continental bedrock and

530 riverine fluxes of strontium and riverine particulate material dissolution in seawater neodymium isotopes to the oceans. Geochem. Geophys. Geosy. 11, Q03016.

532 Pogge von Strandmann, P.A.E., James, R.H., van Calsteren, P., Gislason, S.R., Burton, K.W., 533

Riley, J.P., Chester, R., 1971. Introduction to Marine Chemistry. Academic Press, London.

Siddall, M., Khatiwala, S., van der Flierdt, T., Jones, K., Goldstein, S.L., Hemming, S., 2008. Lithium, magnesium and uranium isotope behaviour in the estuarine environment of basaltic islands. Earth Planet. Sci. Lett. 274, 462-471.

Singh, S.P., Singh, S.K., Goswami, V., Bhushan, R., Rai, V.K., 2012. Spatial distribution of Anderson, R.F., 2008. Towards explaining the Nd paradox using reversible scavenging in an ocean general circulation model. Earth Planet. Sci. Lett. 274, 448-461. dissolved neodymium and $\varepsilon_{\mathrm{Nd}}$ in the Bay of Bengal: Role of particulate matter and mixing of water masses. Geochim. Cosmochim. Acta, 94, 38-56.

Vance, D., Teagle, D., Foster, G., 2009. Variable Quaternary chemical weathering fluxes and imbalances in marine geochemical budgets, Nature 458, 493-496.

Veizer, J., Alab, D., Azmy, K., Bruckschen, P., Buhl, D., Bruhn, F., Cardena, G.A.F., Diener, A., Ebneth, S., Godderis, Y., Jasper, T., Korte, C., Pawellek, F., Podlaha, O.G., Strauss, H., 1999. ${ }^{87} \mathrm{Sr} /{ }^{86} \mathrm{Sr},{ }^{13} \mathrm{C}$ and ${ }^{18} \mathrm{O}$ evolution of Phanerozoic seawater. Chem. Geol. 161, 59-88.

549 Walling, D.E., 2006. Human impact on land-ocean sediment transfer by the world's rivers. $550 \quad$ Geomorphology 79, 192-216. 
551 Wallmann, K., 2001. Controls on the Cretaceous and Cenozoic evolution of seawater composition, atmospheric $\mathrm{CO}_{2}$ and climate. Geochim. Cosmochim. Acta 65, 3005-3025.

553 Wilson D.J., Piotrowski, A.M., Galy. A., McCave N., 2012. A boundary exchange influence on deglacial neodymium isotope records from the deep western Indian Ocean. Earth. Planet. Sci. Let., 341-344, 36-47.

Wolf-Boenisch, D., Gislason, S.R., Oelkers, E.H., Putnis, C.V., 2004. The dissolution rates of natural glasses as a function of their composition at $\mathrm{pH} 4$ and 10.6, and temperatures from

\section{Legends}

561 Fig. 1. A map of western Iceland, showing the sample locations in the Hvítá River and the 562 Borgarfjörður Estuary. The 2003 (black circles) and 2011 (grey circles) transects collected dissolved and suspended samples. The 2003 samples correspond to A4 and C1-11 from previous

564 studies (Pogge von Strandmann et al., 2008). The 2008 transect (black triangles) collected 565 bedload samples.

Fig. 2. A log-log comparison of dissolved $[\mathrm{Sr}]$ and $\lceil\mathrm{Cl}]$ concentrations measured in the 2011 $\underline{\text { samples (grey circles) and } 2003 \text { samples (black circles). The black line represents the pure }}$ mechanical mixing line between the seawater and river water end-members, with the grey shaded area representing the error on this line due to uncertainties associated with the true riverine endmember. 
573 Fig. $\underline{\text { 3. The measured }}{ }^{87} \mathrm{Sr} /{ }^{86} \mathrm{Sr}$ from the dissolved (grey circles) and suspended (grey squares)

574 samples from 2011, and bedload (black triangles) fractions from 2008 against estuarine water

575 dissolved chloride concentrations. The solid curves represent the predicted ${ }^{87} \mathrm{Sr} /{ }^{86} \mathrm{Sr}$ from

576 mechanical two-component mixing of the riverine and seawater end-members, with associated

577 measurement and analytical errors of this line represented by the grey area within the dashed

578 lines. Errors for individual points are well within the size of the symbols.

Fig. 4. The measured ${ }^{87} \mathrm{Sr} /{ }^{86} \mathrm{Sr}$ compared with the fraction of river-derived $[\mathrm{Sr}]$ concentrations.

As with Fig. 2, the black line represents the seawater - river water mechanical mixing line, with

the grey shaded area representing the error on this line due to analytical uncertainties.

Fig. . The difference between the observed ${ }^{87} \mathrm{Sr} /{ }^{86} \mathrm{Sr}$ in dissolved field estuarine water samples and the calculated ${ }^{87} \mathrm{Sr} /{ }^{86} \mathrm{Sr}$ ratios at a given $\mathrm{Cl}$ concentration, based on mechanical two-

586 component mixing (corresponding to the curve in Fig. 2). The model curves represent the

587 calculated deviations from this mechanical mixing, based on experimental release rates from

588 Hvítá bedload (Jones et al., 2012a) and suspended particulates from northeast Iceland (Jones et

589 al., 2012b) in seawater after 1-4 days.

590

Fig. 6. The estimated $\%$ seawater signal between the suspended particles (based on ${ }^{87} \mathrm{Sr} /{ }^{86} \mathrm{Sr}$ ) and dissolved $[\mathrm{Cl}]$ concentrations from the same sample. $[\mathrm{Sr}\rceil \mathrm{vs}[\mathrm{Cl}]$ concentrations are shown for comparison. 

ratios of the bedload particulate material. The symbols correspond to measured concentrations while the line represents the least squares fit of the data.

599 Table 1. Location and chemical data of the water and suspended samples collected in 2011 and 600 2003. n.a. denotes "not analysed" and b.d.l. denotes "below detection limit".

601

602 Table 2. The chemical data of the bedload samples collected in 2008. The "corresponding site" 603 labels match those used in Pogge von Strandmann et al. (2008). * denotes that all Fe is assumed 604 to be as $\mathrm{Fe}^{3+}$.

605

606 Supplementary Information

607 Supplementary Table 1 is a summary of the analyses that calculated the relative release of $\mathrm{Sr}$, 608 based on equations 1-6. 
Highlights (for review)
$\begin{aligned} & \text { - We conducted a suite of field investigations in Borgarfjörður estuary in west Iceland. } \\ & \text { - Dissolved, suspended and bedload }{ }^{87} \mathrm{Sr} /{ }^{86} \mathrm{Sr} \text { values show clear Sr release from particulates. } \\ & \text { - Magnitudes of Sr dissolution agree with experimentally derived values. } \\ & \text { - Sr release from sediments must occur within hours of first contact with saline water. } \\ & \text { - Global Sr flux estimates of comparable magnitude to mid-ocean ridge Sr exchange. }\end{aligned}$

Highlights (for review)
$\begin{aligned} & \text { - We conducted a suite of field investigations in Borgarfjörður estuary in west Iceland. } \\ & \text { - Dissolved, suspended and bedload }{ }^{87} \mathrm{Sr} /{ }^{86} \mathrm{Sr} \text { values show clear Sr release from particulates. } \\ & \text { - Magnitudes of Sr dissolution agree with experimentally derived values. } \\ & \text { - Sr release from sediments must occur within hours of first contact with saline water. } \\ & \text { - Global Sr flux estimates of comparable magnitude to mid-ocean ridge Sr exchange. }\end{aligned}$

Highlights (for review)
$\begin{aligned} & \text { - We conducted a suite of field investigations in Borgarfjörður estuary in west Iceland. } \\ & \text { - Dissolved, suspended and bedload }{ }^{87} \mathrm{Sr} /{ }^{86} \mathrm{Sr} \text { values show clear Sr release from particulates. } \\ & \text { - Magnitudes of Sr dissolution agree with experimentally derived values. } \\ & \text { - Sr release from sediments must occur within hours of first contact with saline water. } \\ & \text { - Global Sr flux estimates of comparable magnitude to mid-ocean ridge Sr exchange. }\end{aligned}$

Highlights (for review)
$\begin{aligned} & \text { - We conducted a suite of field investigations in Borgarfjörður estuary in west Iceland. } \\ & \text { - Dissolved, suspended and bedload }{ }^{87} \mathrm{Sr} /{ }^{86} \mathrm{Sr} \text { values show clear Sr release from particulates. } \\ & \text { - Magnitudes of Sr dissolution agree with experimentally derived values. } \\ & \text { - Sr release from sediments must occur within hours of first contact with saline water. } \\ & \text { - Global Sr flux estimates of comparable magnitude to mid-ocean ridge Sr exchange. }\end{aligned}$

Highlights (for review)
$\begin{aligned} & \text { - We conducted a suite of field investigations in Borgarfjörður estuary in west Iceland. } \\ & \text { - Dissolved, suspended and bedload }{ }^{87} \mathrm{Sr} /{ }^{86} \mathrm{Sr} \text { values show clear Sr release from particulates. } \\ & \text { - Magnitudes of Sr dissolution agree with experimentally derived values. } \\ & \text { - Sr release from sediments must occur within hours of first contact with saline water. } \\ & \text { - Global Sr flux estimates of comparable magnitude to mid-ocean ridge Sr exchange. }\end{aligned}$

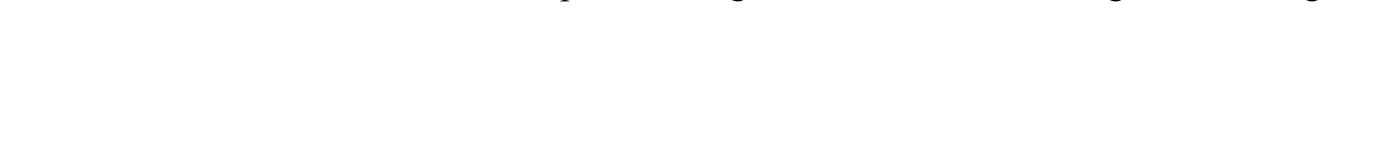

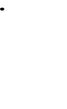

.

(2)

.

(2)

.

(1)

(1)

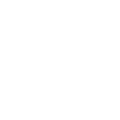

( 更

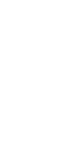
更

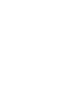
更 更 更 更 更 更 更 更 更 更 更 更 更 更 更 


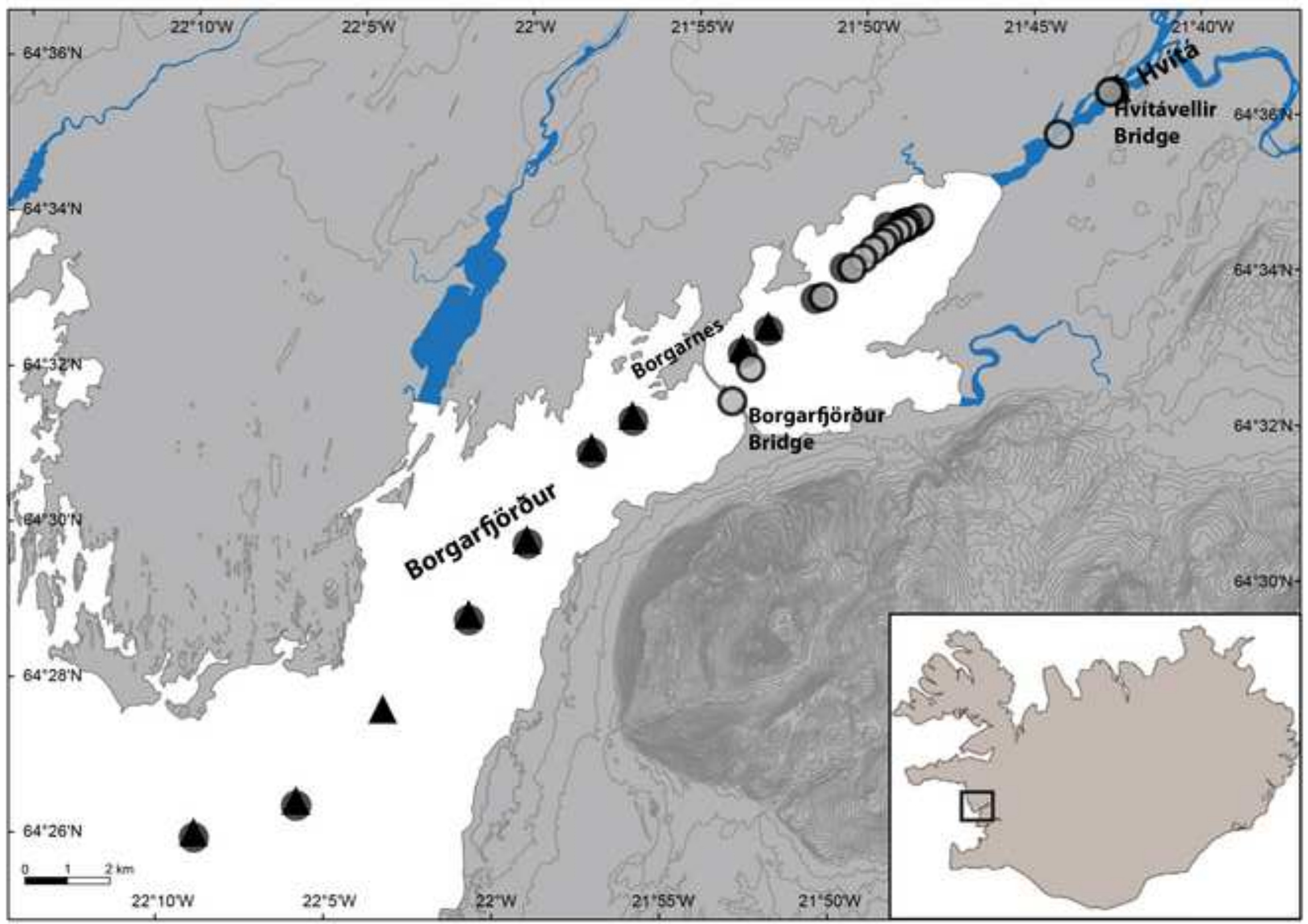


Click here to download high resolution image

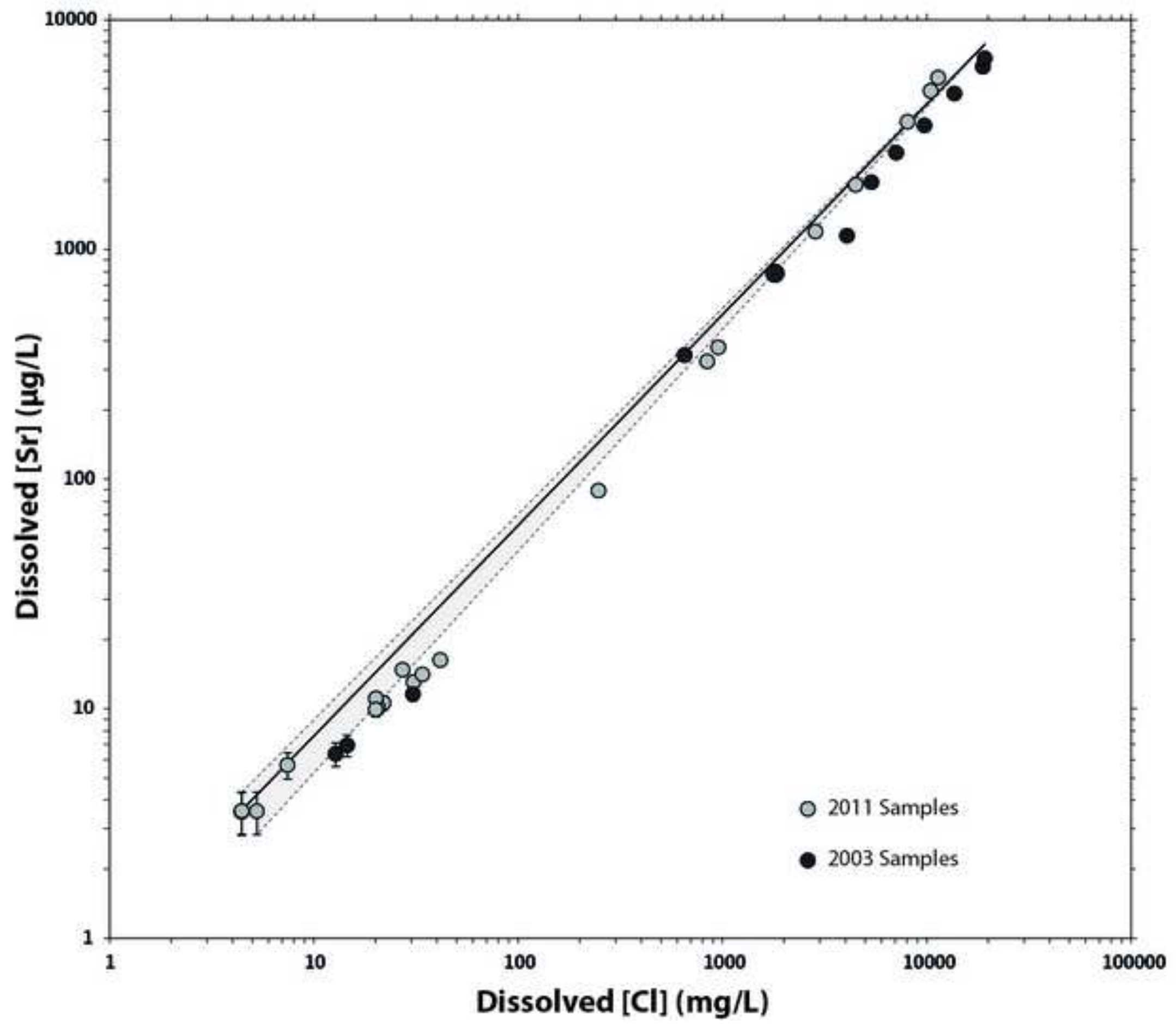




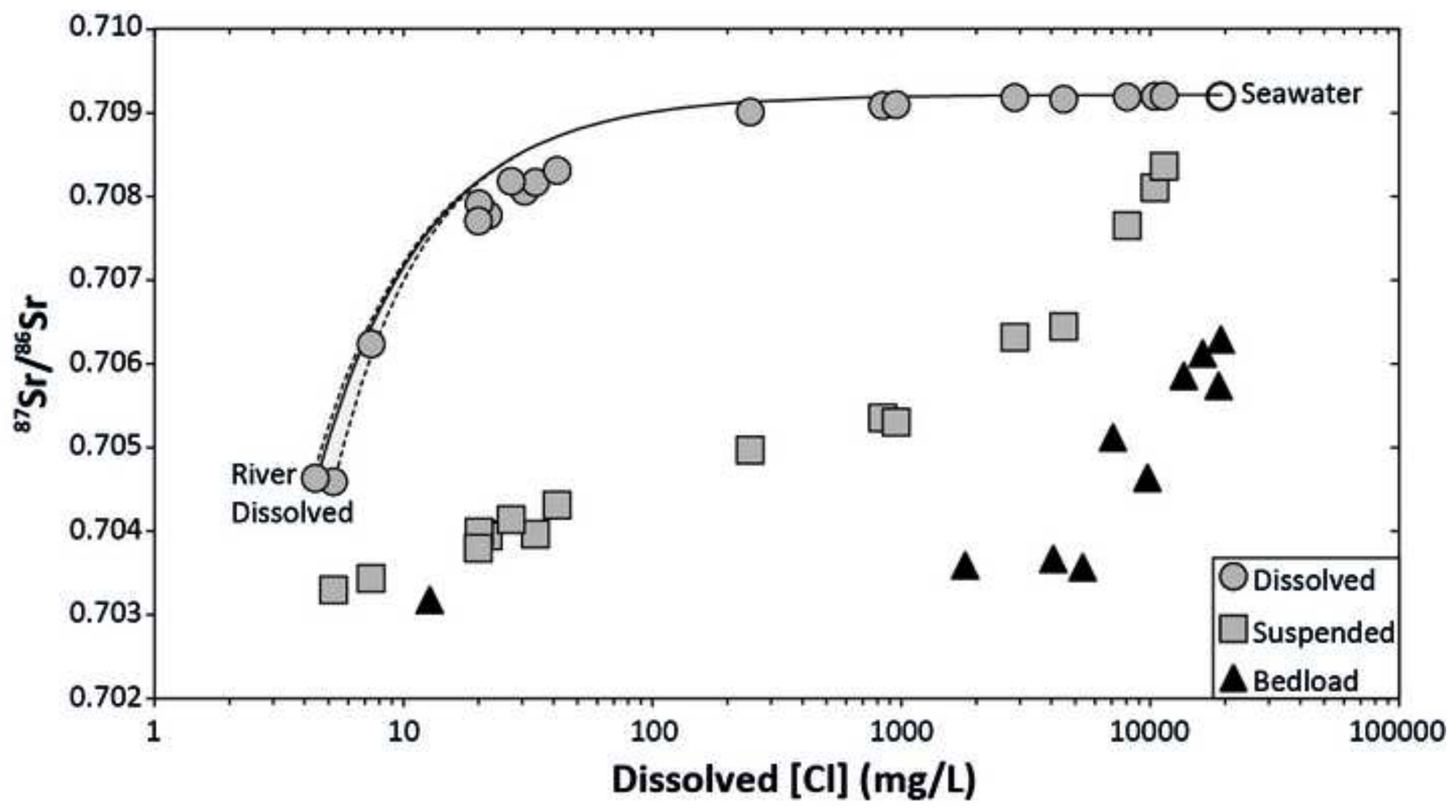




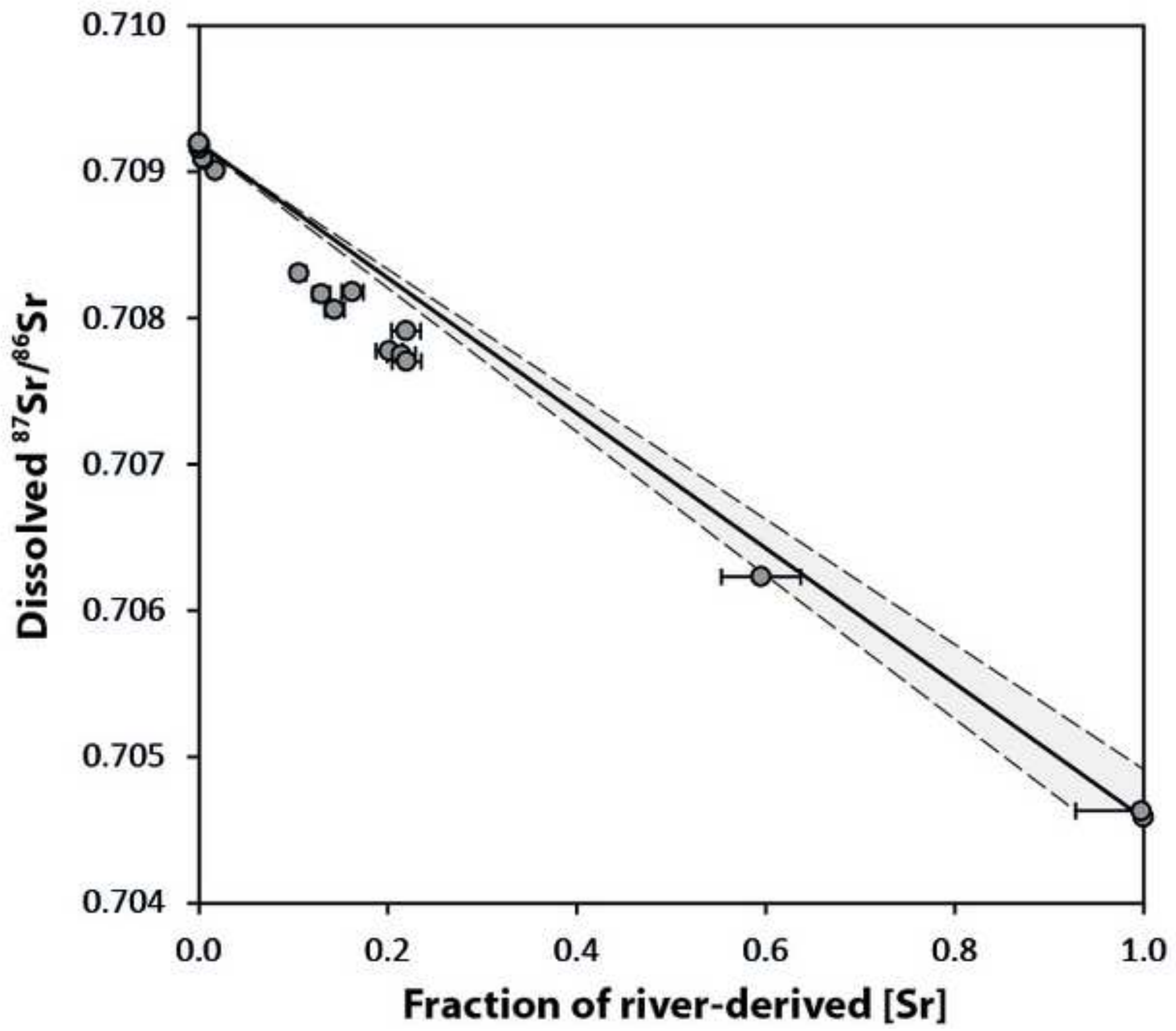




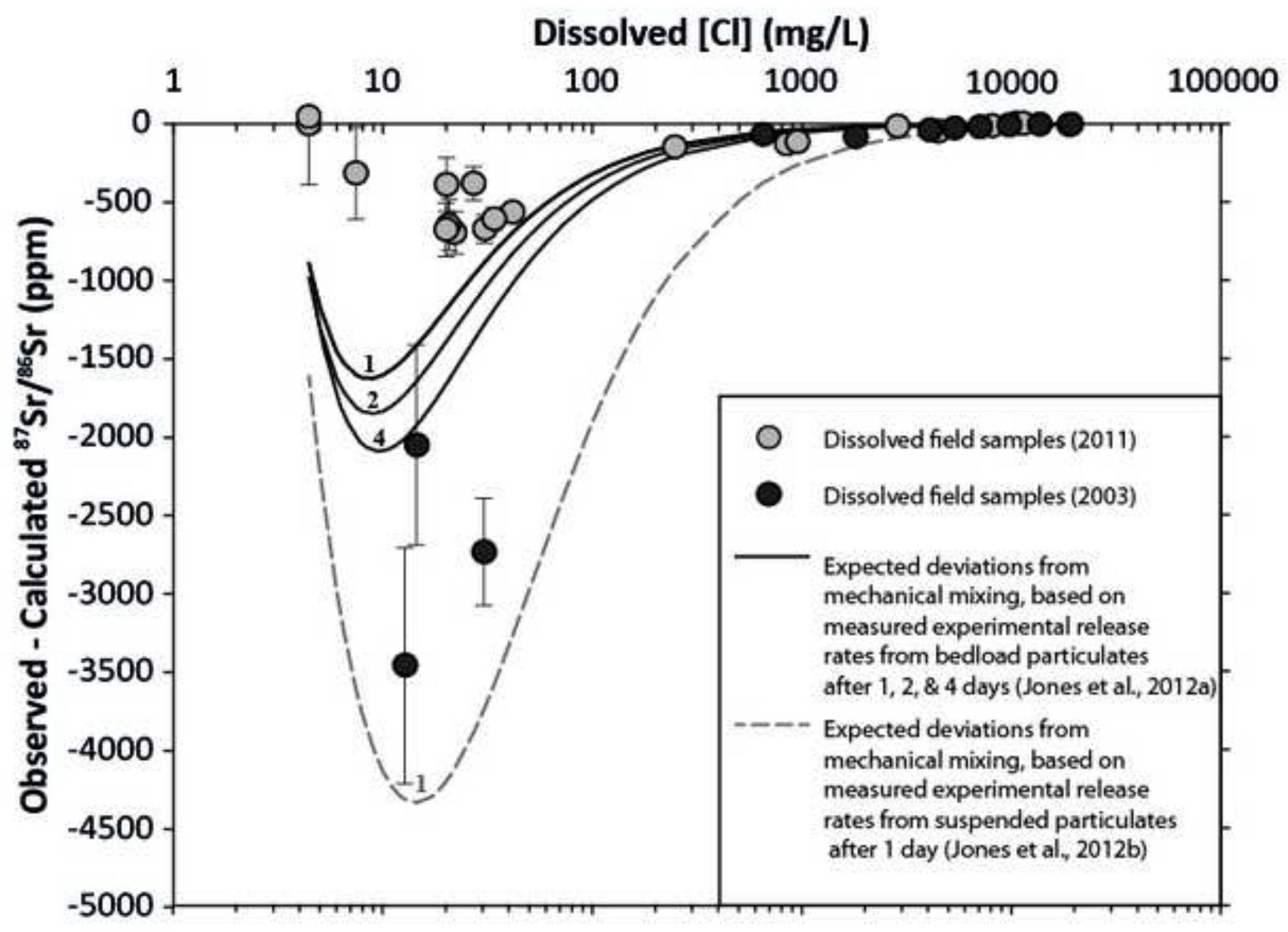




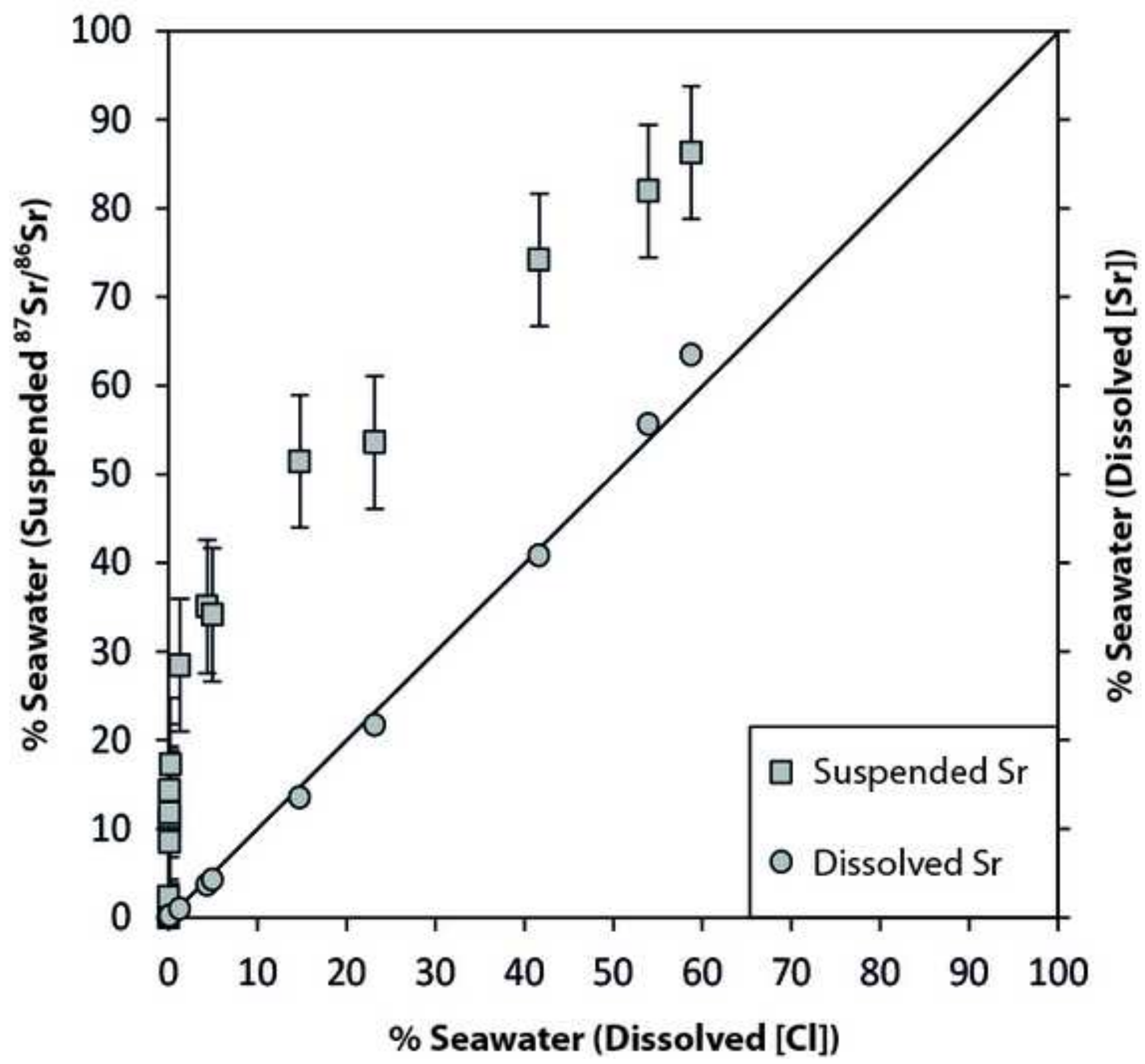




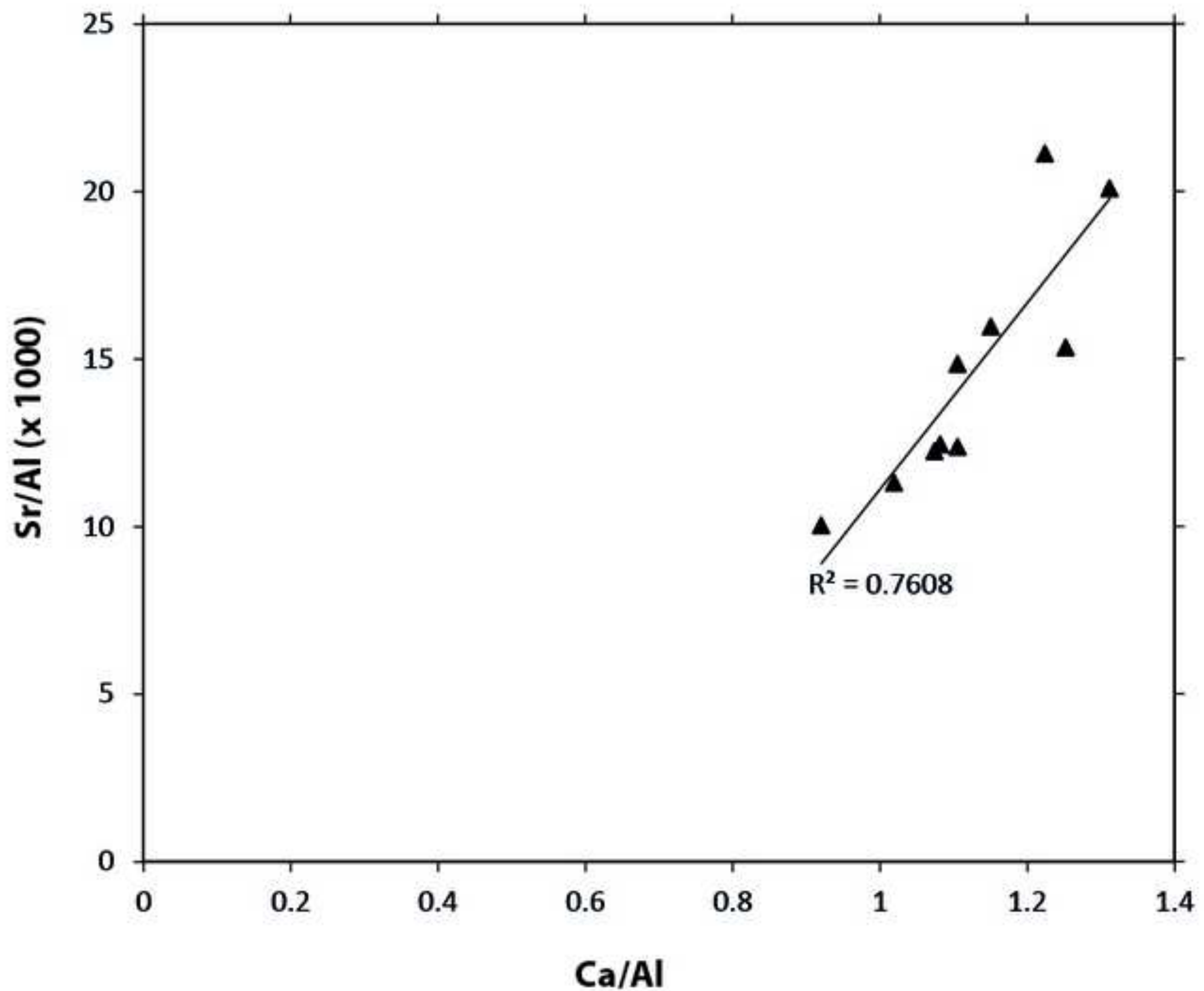




\begin{tabular}{|c|c|c|c|c|c|c|c|c|c|c|c|c|c|c|c|c|c|c|c|c|c|c|c|c|c|c|c|c|}
\hline Site & Latitude & Longitude & Date & Time & $\begin{array}{l}\text { Distance from } \\
\text { Hvitávellir }\end{array}$ & Water Temp. & $\mathrm{pH}$ & Conductivity & Salinity & $\begin{array}{c}\text { Suspended } \\
\text { Fraction }\end{array}$ & Alkalinity & $\mathrm{cl}$ & $\mathrm{SO}_{4}$ & $\mathrm{Si}$ & $\mathrm{Na}$ & k & ca & Mg & $\mathrm{Fe}$ & Al & $\mathrm{Mn}$ & $\mathrm{Li}$ & $\mathrm{Br}$ & B & $\mathrm{Sr}$ & Dissolved ${ }^{87} \mathrm{Sr} / /^{86} \mathrm{Sr}$ & Suspended Sr & 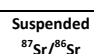 \\
\hline 2011 Data & & & & & $\mathrm{km}$ & ${ }^{\circ} \mathrm{C}$ & & $\mathrm{ms}$ & $\%$ of S.W. & $\mathrm{mg} / \mathrm{L}$ & $\mathrm{meq} / \mathrm{L}$ & $\mathrm{mg} / \mathrm{L}$ & $\mathrm{mg} / \mathrm{L}$ & $\mathrm{mg} / \mathrm{L}$ & $\mathrm{mg} / \mathrm{L}$ & $\mathrm{mg} / \mathrm{L}$ & $\mathrm{mg} / \mathrm{L}$ & & $\mathrm{mg} / \mathrm{L}$ & $\mu \mathrm{g} / \mathrm{L}$ & $\mu \mathrm{g} / \mathrm{L}$ & $\mu \mathrm{g} / \mathrm{L}$ & $\mathrm{mg} / \mathrm{L}$ & $\mathrm{mg} / \mathrm{L}$ & $\mu \mathrm{g} / \mathrm{L}$ & & $\mathrm{mg} / \mathrm{kg}$ & \\
\hline HvA & $64^{\circ} 36^{\prime} 11.0^{\prime \prime}$ & $021^{\circ} 42^{\prime} 37.5^{\prime \prime}$ & $25 / 08 / 2011$ & 14:55 & 0.00 & 7.7 & 8.08 & 0.06 & 0.03 & 562 & 0.390 & 5.3 & 0.4 & 6.51 & 6.7 & 0.5 & 3.1 & & & 71.5 & 1.67 & 0.18 & 0.014 & 0.005 & 3.6 & 0.704589 & 228.3 & 0.703294 \\
\hline HvB & $64^{\circ} 36^{\prime} 11.0^{\prime \prime}$ & $021^{\circ} 42^{\prime} 37.5^{\prime \prime}$ & $25 / 08 / 2011$ & 15:25 & 0.00 & & 8.08 & 0.07 & 0.02 & 560 & 0.385 & 4.4 & 0.2 & 6.43 & 6.6 & 0.4 & 3.0 & & 0.008 & 61.3 & 1.16 & 0.14 & 0.013 & 0.004 & 3.6 & & n.a & n. \\
\hline Bo1 & $64^{\circ} 35^{\prime} 36.8^{\prime \prime}$ & $021^{\circ} 44^{\prime} 06.5^{\prime \prime}$ & $25 / 08 / 2011$ & 16:10 & 1.57 & 7.5 & 8.08 & 0.06 & 0.02 & 507 & 0.393 & 4.4 & 0.2 & 6.29 & 6.9 & 0.4 & 3.0 & & 0.009 & 59.9 & 0.57 & 0.17 & 0.003 & 0.003 & 3.6 & 31 & 177.9 & \\
\hline Bo6 & $64^{\circ} 34^{\prime} 27.1^{\prime \prime}$ & $021^{\circ} 48^{\prime} 09.7^{\prime \prime}$ & $25 / 08 / 2011$ & 17:00 & 5.43 & 8.6 & 7.81 & 0.08 & 0.04 & 505 & 0.450 & 7.4 & 0.8 & 6.38 & 8.7 & 0.5 & 3.1 & & 0.013 & 61.0 & 1.95 & 0.23 & 0.014 & 0.005 & 5.7 & 233 & 159.2 & 0.703430 \\
\hline Bo2 & $64^{\circ} 34^{\prime} 24.1^{\prime \prime}$ & $021^{\circ} 48^{\prime} 16.7^{\prime \prime}$ & $25 / 08 / 2011$ & 16:40 & 5.54 & 9.5 & 7.80 & 0.07 & 0.16 & 506 & 0.402 & 30.7 & 5.5 & 6.50 & 21.3 & 1.0 & 3.1 & & & 51.0 & 4.97 & 0.56 & 0.074 & 0.015 & 13.1 & & 180.3 & \\
\hline Bo5 & $64^{\circ} 34^{\prime} 25.0^{\prime \prime}$ & & & & & 9.8 & 7.81 & & 0.11 & 499 & 0.406 & 21.9 & 3.9 & 6.46 & 16.9 & 0.9 & 31 & 2.20 & & & 4.46 & 45 & 0.072 & & 10.6 & & 74.9 & 40 \\
\hline Bo7 & & & & & & 9.5 & 7.78 & & 0.21 & 486 & 0.407 & 41.6 & 7.8 & 6.51 & 27.6 & 1.3 & 3.3 & 3.20 & & 52.1 & 4.29 & 174 & 0.123 & & 16.3 & & 63.5 & 0.704309 \\
\hline Bo4 & $64^{\circ} 34^{\prime} 23.7^{\prime \prime}$ & $021^{\circ} 48^{\prime}$ & & & & 5 & 7.81 & & 0.11 & 501 & & 20.6 & 3.5 & 6.49 & 16.0 & 0.8 & 3.0 & 2.10 & & & 32 & & 0.063 & & 10.2 & & 75.2 & \\
\hline Bo3 & $64^{\circ} 34^{\prime} 22.6^{\prime \prime}$ & $021^{\circ} 48^{3} 39.3^{\prime \prime}$ & & 16:50 & & .9 & 7.82 & & 0.18 & 505 & 0.460 & 34.0 & 6.1 & 6.41 & 23.9 & 1.1 & 3.1 & 2.80 & 0.011 & & 4. & & 0.112 & & 1.2 & & 0.3 & 39960 \\
\hline $\begin{array}{l}\text { Bo8 } \\
\text { Bo8-b }\end{array}$ & $64^{\circ} 34^{\prime} 19.6^{\prime \prime \prime}$ & & & 17:10 & & 8 & 7.78 & & & 489 & 0.401 & 20.1 & 4.3 & 6.56 & 18.0 & 1.1 & 1 & 40 & & & & 184 & & & 11.1 & & 51.8 & 03987 \\
\hline $\begin{array}{l}\text { Bo8-b } \\
\text { Bog }\end{array}$ & 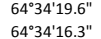 & 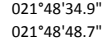 & $\begin{array}{l}25 / 08 / / 2011 \\
25 / 20812\end{array}$ & $\begin{array}{l}17: 12 \\
17: 15\end{array}$ & $\begin{array}{l}5.83 \\
6.04\end{array}$ & $\begin{array}{l}9.6 \\
9.6\end{array}$ & $\begin{array}{l}7.77 \\
7.78\end{array}$ & $\begin{array}{l}0.13 \\
0.18\end{array}$ & $\begin{array}{l}0.10 \\
0.14\end{array}$ & $\begin{array}{l}747 \\
493\end{array}$ & $\begin{array}{l}0.400 \\
0.453\end{array}$ & $\begin{array}{l}20.1 \\
27.2\end{array}$ & $\begin{array}{l}3.4 \\
6.1\end{array}$ & $\begin{array}{l}6.54 \\
674\end{array}$ & $\begin{array}{l}15.6 \\
226\end{array}$ & $\begin{array}{l}0.8 \\
11\end{array}$ & $\begin{array}{l}3.0 \\
3.3\end{array}$ & $\begin{array}{l}2.10 \\
3.10\end{array}$ & $\begin{array}{l}0.011 \\
0.019\end{array}$ & $\begin{array}{l}52.1 \\
610\end{array}$ & $\begin{array}{l}2.84 \\
3.26\end{array}$ & $\begin{array}{l}0.17 \\
0.82\end{array}$ & 0.072 & 0.009 & 10.0 & 17705 & $\begin{array}{l}299.0 \\
1558\end{array}$ & 03795 \\
\hline Bo10 & $\begin{array}{l}64^{6} 34^{\circ} 16.3^{\prime \prime \prime} \\
64^{\prime \prime} 14^{12}\end{array}$ & $\begin{array}{l}2011^{4} 48^{8} 89^{\prime \prime \prime} \\
021^{\prime \prime}\end{array}$ & $\begin{array}{l}25 / 808 / / 2011 \\
25 / / 88 / 2011\end{array}$ & $\begin{array}{l}17: 15 \\
17: 20\end{array}$ & $\begin{array}{l}6.04 \\
6.26\end{array}$ & $\begin{array}{l}9.6 \\
9.6\end{array}$ & $\begin{array}{l}.7 .18 \\
7.77\end{array}$ & $\begin{array}{l}0.18 \\
0.93\end{array}$ & $\begin{array}{l}0.14 \\
1.28\end{array}$ & 493 & $\begin{array}{l}0.453 \\
0.431\end{array}$ & $\begin{array}{r}27.2 \\
247.6\end{array}$ & $\begin{array}{r}6.1 \\
24.7\end{array}$ & $\begin{array}{l}6.74 \\
6.45\end{array}$ & $\begin{array}{r}22.6 \\
1310\end{array}$ & $\begin{array}{l}1.1 \\
5.4\end{array}$ & $\begin{array}{l}3.3 \\
7.4\end{array}$ & & $\begin{array}{l}0.019 \\
0.014\end{array}$ & $\begin{array}{l}61.0 \\
55.8\end{array}$ & $\begin{array}{l}3.26 \\
3.93\end{array}$ & 0.82 & 0.104 & 0.012 & 14.8 & 88179 & $\begin{array}{l}155.8 \\
1519\end{array}$ & 0.704135 \\
\hline Bo11 & $64^{\circ} 34^{\prime} 07.5^{\prime \prime}$ & $021^{\circ} 49^{\prime} 13.6^{\prime \prime}$ & $25 / 08 / 2011$ & $17: 25$ & 6.45 & 9.3 & 7.81 & 3.62 & 4.35 & $\begin{array}{l}492 \\
494\end{array}$ & $\begin{array}{l}0.431 \\
0.492\end{array}$ & 843.5 & $\begin{array}{l}24.7 \\
174.6\end{array}$ & $\begin{array}{l}6.45 \\
6.18\end{array}$ & $\begin{array}{l}111.0 \\
4710\end{array}$ & $\begin{array}{r}5.4 \\
\quad 180\end{array}$ & 7.4 & $\begin{array}{l}16.10 \\
5740\end{array}$ & & $\begin{array}{l}55.8 \\
48.5\end{array}$ & 3.9 & 8. & 0.739 & 0.0 & 89.2 & & 151.9 & 0.704966 \\
\hline Bo12 & $64^{\circ} 34^{\prime} 01.5^{\prime \prime}$ & $021^{\circ} 49^{\prime}$ & & $17: 29$ & 6.74 & 9.5 & 7.84 & 4.14 & 4.92 & 96 & $\begin{array}{l}0.452 \\
0.502\end{array}$ & 954.8 & 183.7 & $\begin{array}{l}0.10 \\
6.12\end{array}$ & $\begin{array}{l}471.0 \\
5780\end{array}$ & 2806 & 21.0 & & 0.009 & 48 & 4.1 & & & & & & $\begin{array}{l}151.1 \\
145.9\end{array}$ & 0.705355 \\
\hline Bo13 & $64^{\circ} 33^{\prime}$ & $021^{\circ} 4$ & & $17: 32$ & 7.05 & 0 & 7.98 & n.a & 14.75 & $\begin{array}{l}499 \\
\end{array}$ & $\begin{array}{l}0.032 \\
0.770\end{array}$ & $\begin{array}{l}2861.2 \\
\end{array}$ & 574.4 & $\begin{array}{l}6.12 \\
5.37\end{array}$ & 1700.0 & $\begin{array}{l}20.6 \\
65.1\end{array}$ & $\begin{array}{l}23.9 \\
70.4\end{array}$ & $\begin{array}{r}66.50 \\
213.00\end{array}$ & & $\begin{array}{l}49.4 \\
41.8\end{array}$ & $\begin{array}{l}5.02 \\
7.86\end{array}$ & $\begin{array}{l}9.8 .1 \\
21.1\end{array}$ & $\begin{array}{r}3.314 \\
10.427\end{array}$ & & 0 & & 02.3 & 66315 \\
\hline Bo14 & $64^{\circ} 33^{\prime \prime}$ & & & $17: 36$ & & & 8.00 & n.a & 23.19 & 517 & 0.901 & 4498.2 & 980.1 & 4.62 & 2880.0 & 102.0 & 111.0 & 336.0 & b.d.l & 36 & 8. & 54. & 17. & & .0 & & 50.1 & \\
\hline Bo15 & $64^{\circ} 33^{\prime 2}$ & & & 17:40 & & & 8.11 & n.a & 41.67 & 651 & 1.389 & 8084.8 & n.a & 3.06 & 5550.0 & 199.0 & 205.0 & 642.00 & 0.005 & 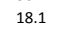 & 8 & 85 & 31. & & .0 & & 146.5 & \\
\hline Bo16 & & 02 & & $17: 45$ & 74 & 0 & 8.12 & n.a & 53.92 & n.a & 20 & 10460.9 & n.a & 2.08 & 7450.0 & & 2780 & 861.0 & b.d.l & 120 & 7 & 109.19 & 12 & 20 & 920.0 & & 43.9 & \\
\hline Bo17 & $64^{\circ} 31^{1} 59.6^{\prime \prime}$ & $021^{\circ} 53^{3} 31.2^{\prime \prime}$ & $25 / 08 / 2011$ & $17: 52$ & 11.57 & 10.5 & 8.08 & n.a & 58.78 & n.a & 1.836 & 11402.8 & n.a & 1.50 & 8460.0 & 306. & 315.0 & 977.0 & b.d.l. & 10.6 & 6.95 & 111.30 & 48.553 & 3.620 & 5610.0 & 0.709198 & 139.1 & 0.708359 \\
\hline
\end{tabular}

\begin{tabular}{|c|c|c|c|c|c|c|c|c|c|c|c|c|c|c|c|c|c|c|c|c|c|c|c|c|c|c|c|}
\hline Site & Latitude & Longitude & Date & Time & $\begin{array}{l}\text { Distance from } \\
\text { Hvitávellir }\end{array}$ & Temp. & $\mathrm{pH}$ & Conductivity & Salinity & $\begin{array}{c}\text { Suspended } \\
\text { Fraction }\end{array}$ & Alkalinity & TDS & cl & $\mathrm{SO}_{4}$ & $\mathrm{Na}$ & k & ca & Mg & Li & Sr & $\begin{array}{l}\text { Dissolved } \\
{ }^{8} 7 \mathrm{~s} / \mathrm{r}^{8 / 5} \mathrm{sr}\end{array}$ & $\begin{array}{c}\text { Suspended } \\
\mathrm{Sr}\end{array}$ & 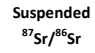 & 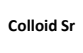 & $\begin{array}{l}\text { Colloid } \\
{ }^{87} \mathrm{rr} /{ }^{80} \mathrm{sr}\end{array}$ & $\begin{array}{l}\text { Suspended Fe-Mn } \\
\text { Leachate Sr }\end{array}$ & 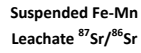 \\
\hline 2003 Dat: & & & & & $\mathrm{km}$ & & c & $\mathrm{ms}$ & \% of s.W. & $\mathrm{mg} / \mathrm{L}$ & $\mathrm{meq} / \mathrm{L}$ & $\mathrm{mg} / \mathrm{L}$ & $\mathrm{mg} / \mathrm{L}$ & $\mathrm{mg} / \mathrm{L}$ & $\mathrm{mg} / \mathrm{L}$ & $\mathrm{mg} / \mathrm{L}$ & $\mathrm{L} \mathrm{mg} / \mathrm{L}$ & $\mathrm{mg} / \mathrm{L}$ & $\mu \mathrm{g} / \mathrm{L}$ & $\mathrm{mg} / \mathrm{L}$ & & $\mathrm{mg} / \mathrm{kg}$ & & $\mathrm{mg} / \mathrm{kg}$ & & $\mathrm{mg} / \mathrm{kg}$ & \\
\hline$\overline{\mathrm{A4}}$ & $\begin{array}{l}\mathrm{N} 64^{\circ} 36.199^{\prime} \\
\end{array}$ & 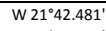 & \begin{tabular}{|c|c|}
$09 / 09 / 2003$ \\
\end{tabular} & $\begin{array}{l}09: 30 \\
\end{array}$ & 0.00 & & 07.93 & 0.07 & 0.1 & 610 & 0.473 & 34.7 & 12.8 & 0.5 & 57.1 & 0.5 & $\begin{array}{|ll|}5 & 3.9 \\
\end{array}$ & 1.9 & 0.3 & 6.4 & 0.705155 & 192 & 0.703344 & 0.00056 & 0.704567 & 1.78 & 0.704555 \\
\hline c1 & $\mathrm{N} 64^{\circ} 34.290^{\prime}$ & ' W21 $21^{49} .299^{\prime}$ & 09/09/2003 & 08:20 & 6.43 & & 77.92 & 0.07 & 0.2 & n.a & n.a & 33.4 & 14.5 & 0.8 & 7.5 & 0.5 & $\begin{array}{l}5 \\
5\end{array} 4.2$ & 6.4 & 0.3 & 6.9 & 0.706343 & n.a & 0.703347 & n.a & n.a & n.a & n.a \\
\hline c2 & N 64'33.584' & ' W21 $1^{\circ} 51.107^{\prime}$ & 09/09/2003 & 08:40 & 8.42 & & 07.95 & 0.09 & 0.2 & n.a & n.a & 47.2 & 30.5 & 1.0 & 12.9 & 0.7 & $\begin{array}{l}7 \quad 4.3 \\
\end{array}$ & 2.0 & 0.4 & 11.6 & 0.706593 & n.a & 0.703485 & n.a & n.a & n.a & n.a \\
\hline c3 & N 64'33.207' & W $21^{\circ} 51.792$ & o9/09/2003 & 09:10 & 9.21 & & 87.94 & 2.89 & 5.4 & n.a & n.a & 1419 & 652.3 & 218.1 & 547.2 & 25.0 & $\begin{array}{ll}0 & 26.8 \\
0 & \end{array}$ & 2.7 & 9.4 & 346.6 & 0.709118 & 210 & 0.706838 & n.a & n.a & n.a & n.a \\
\hline${ }^{c 4}$ & N 64"32.924' & W $21^{1} 52.529^{\prime}$ & | 09/09/2003 & $09: 45$ & 10.00 & & $\begin{array}{l}48.08 \\
-08\end{array}$ & 7.15 & 13.3 & n.a & n.a & 3570 & 1808.1 & 309.3 & 31142.6 & 51.6 & $6 \quad 51.7$ & 67.1 & 21.0 & 788.5 & 0.709127 & 201 & 0.707744 & n.a & n.a & n.a & n.a \\
\hline c5 & N 64"32.623' & w $211^{\circ 533.270^{\prime}}$ & | 09/09/2003 & 10:00 & 84 & & 68.16 & 9.8 & 19.1 & n.a & n.a & 4900 & 4077.1 & 576.3 & 31676.0 & 75.9 & 972.5 & 139.0 & 30.31 & 1147.8 & & 195 & 0.708191 & n.a & n.a & n.a & n.a \\
\hline${ }^{c 6}$ & N 64"31.686' & W $21^{1} 56.450^{\prime}$ & , 09/09, & 10:10 & 94 & 9 & 88.22 & 12.91 & 4.8 & n.a & n.a & 6460 & 5353.4 & 714.7 & 2666.8 & 118.5 & 5113.8 & 325.7 & 48.01 & 1962.7 & 0.709176 & 199 & 0.708359 & n.a & n.a & n.a & n.a \\
\hline C7 & N 64 $4^{\circ} 31.240^{\prime}$ & W $21^{1} 57.6477$ & & 10:30 & $\begin{array}{l}15.18 \\
1177\end{array}$ & 10 & $\begin{array}{l}48.25 \\
7\end{array}$ & $\begin{array}{l}15.27 \\
21.79\end{array}$ & 29.7 & n.a & n.a & $\begin{array}{r}7660 \\
7090\end{array}$ & 7090.6 & 810.7 & $\begin{array}{l}3747.3 \\
37589\end{array}$ & 162.3 & $\begin{array}{l}3156.7 \\
6\end{array}$ & $\begin{array}{l}454.5 \\
578.5\end{array}$ & 71.52 & & & 212 & 0.708505 & n.a & n.a & n.a & n.a \\
\hline $\begin{array}{l}c 8 \\
c 9\end{array}$ & $\begin{array}{ll}N & 64^{\circ} 30.035^{\prime}\end{array}$ & W $211^{15} 5$ & $09 / 09$ & $\begin{array}{l}30: 40 \\
31100\end{array}$ & 71 & 10 & $\begin{array}{l}78.27 \\
18.20\end{array}$ & 79 & $\begin{array}{l}41.2 \\
55.6\end{array}$ & n.a & n.a & 10930 & 9749.6 & 1075.8 & 3758.9 & 198.6 & 6194.8 & 578.5 & 90.23 & 3469.8 & & 77 & & n.a & n.a & n.a & n.a \\
\hline $\begin{array}{l}\mathrm{Cg} \\
\mathrm{c} 10\end{array}$ & 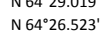 & $\begin{array}{l}w 21 \\
w \\
w 20\end{array}$ & $\begin{array}{l}09 / / 99 / 2003 \\
09 / / 99 / 2003\end{array}$ & $\begin{array}{l}11: 05 \\
11: 20\end{array}$ & $\begin{array}{l}19.90 \\
25.94\end{array}$ & $\begin{array}{l}11 \\
11\end{array}$ & 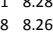 & $\begin{array}{l}\begin{array}{r}0.80 \\
44.20\end{array}\end{array}$ & $\begin{array}{l}58.6 \\
87.2\end{array}$ & $\begin{array}{l}\text { n.a } \\
\text { n.a }\end{array}$ & $\begin{array}{l}\text { n.a } \\
\text { n.a }\end{array}$ & $\begin{array}{l}15500 \\
21700\end{array}$ & $\begin{array}{l}\begin{array}{l}134699.4 \\
18825.5\end{array} \\
\end{array}$ & $\begin{array}{l}1848.9 \\
2218.9\end{array}$ & 9149.9 & $\begin{array}{l}2838.1 \\
406.6\end{array}$ & 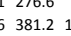 & $\begin{array}{r}806.93 \\
1125.3\end{array}$ & $\begin{array}{l}121.54 \\
155.56\end{array}$ & $\begin{array}{l}4745.3 \\
6247.3\end{array}$ & $\begin{array}{l}0.109194 \\
0.709194\end{array}$ & $\begin{array}{r}\text { n.a } \\
\text { n.a }\end{array}$ & $\begin{array}{l}0.708576 \\
\text { n.a }\end{array}$ & $\begin{array}{l}\text { n.a } \\
\text { n.a }\end{array}$ & 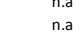 & $\begin{array}{l}\text { n.a } \\
\text { n.a }\end{array}$ & $\begin{array}{l}\text { n.a } \\
\text { n.a }\end{array}$ \\
\hline $\mathrm{C} 11$ & $\mathrm{~N} 64^{\circ} 26.050^{\prime}$ & W $222^{\circ} 08.966^{\prime}$ & 09/09/2003 & $11: 45$ & 28.33 & 12 & 18.29 & 47.10 & 90.6 & n.a & n.a & 23500 & 19215.5 & 2286.2 & 9632.7 & 422.3 & 3404.81 & 1183.7 & $163.1 \mathrm{G}$ & 6799.3 & 0.709194 & 14.2 & 0.708699 & n.a & n.a & n.a & n.a \\
\hline
\end{tabular}


Click here to download Table: Table 2.xIsx

\begin{tabular}{|c|c|c|c|c|c|c|}
\hline 2008 Bedload & Bed 1 & Bed 2 & Bed 3 & Bed 4 & Bed 5 & Bed 6 \\
\hline $\begin{array}{l}\text { Corresponding } \\
\text { site }\end{array}$ & A4 & C4 & C5 & C6 & $\mathrm{C} 7$ & C8 \\
\hline$\overline{\text { Lat. }}$ & N 643‥199' & N 64ㅇ․ $32.924^{\prime}$ & N 64'32.623' & 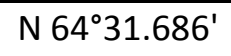 & $\mathrm{N} 64^{\circ} 31.240^{\prime}$ & $\mathrm{N} 64^{\circ} 30.035^{\prime}$ \\
\hline Long. & W $21^{\circ} 42.481^{\prime}$ & W $21^{\circ} 52.529^{\prime}$ & W $21^{\circ} 53.270^{\prime}$ & W $21^{\circ} 56.450^{\prime}$ & W $21^{\circ} 57.647^{\prime}$ & W $21^{\circ} 59.427^{\prime}$ \\
\hline BET $\left(m^{2} g^{-1}\right)$ & 6.358 & 11.14 & 9.603 & 9.756 & 12.38 & 8.404 \\
\hline $\mathrm{SiO}_{2}(\%)$ & 46.74 & 46.29 & 45.81 & 46.82 & 44.94 & 45.30 \\
\hline $\mathrm{Na}_{2} \mathrm{O}(\%)$ & 2.67 & 2.40 & 2.19 & 2.28 & 2.72 & 2.20 \\
\hline $\mathrm{MgO}(\%)$ & 8.17 & 9.00 & 9.00 & 8.51 & 7.20 & 9.75 \\
\hline $\mathrm{Al}_{2} \mathrm{O}_{3}(\%)$ & 15.24 & 13.06 & 13.07 & 13.70 & 13.24 & 11.46 \\
\hline $\mathrm{P}_{2} \mathrm{O}_{5}(\%)$ & 0.14 & 0.12 & 0.13 & 0.12 & 0.17 & 0.13 \\
\hline $\mathrm{K}_{2} \mathrm{O}(\%)$ & 0.28 & 0.39 & 0.33 & 0.38 & 0.49 & 0.38 \\
\hline $\mathrm{CaO}(\%)$ & 14.02 & 14.02 & 14.14 & 13.96 & 14.63 & 14.35 \\
\hline $\mathrm{TiO}_{2}(\%)$ & 1.45 & 1.49 & 1.56 & 1.44 & 1.49 & 1.57 \\
\hline $\mathrm{MnO}(\%)$ & 0.24 & 0.20 & 0.20 & 0.19 & 0.16 & 0.18 \\
\hline $\mathrm{Fe}_{2} \mathrm{O}_{3} *(\%)$ & 10.81 & 11.46 & 11.90 & 11.52 & 12.42 & 12.99 \\
\hline $\mathrm{Sr}\left(\mathrm{mg} \mathrm{kg}^{-1}\right)$ & 152.90 & 159.94 & 162.64 & 154.90 & 196.53 & 175.92 \\
\hline${ }^{87} \mathrm{Sr} /{ }^{86} \mathrm{Sr}$ & 0.703180 & 0.703591 & 0.703668 & 0.703569 & 0.705118 & 0.704637 \\
\hline
\end{tabular}



Supplementary material for on-line publication only
Click here to download Supplementary material for

x Click here to download Supplementary material for on-line publication only: Supplementary Table 1.xIsx
lick here to download Supplementary ( publication only: Sul (1) (1) (1) . . . . . . . . . . . . . . . . 